WATER-RESOURCES INVESTIGATIONS OF THE

U.S. GEOLOGICAL SURVEY NEW MEXICO DISTRICT

FISCAL YEAR 1978

Compiled by P. L. Soule and D. W. Wilkins

U.S. GEOLOGICAL SURVEY

Open-File Report 79-560

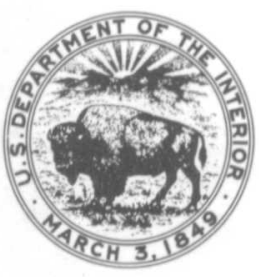

March 1979 
This is the first of an annual series of reports in which the program of the New Mexico District, U.S. Geological Survey, Water Resources Division, will be summarized. This report should be useful to cooperating agencies and to the users of water data in that it summarizes and gives the status of the basic data collection program and al1 current studies of the Water Resources Division in New Mexico.

The program of the New Mexico District is, for the most part, accomplished through cooperative programs with other Federal and non-Federal agencies. 
Surface-water data - 18

Ground-water data - 20

Chemical-quality and biological water data - 22

Sediment data - 24

Interpretive hydrologic investigations

Flood insurance studies - 26

Duties for the Rio Grande Compact Commission - - 26

Miscellaneous activities under the State Engineer

Program -

A quantitative analysis of the ground-water system in the Roswell basin, Chaves and Eddy Counties,

New Mexico - 30

New Mexico District Data Bank-_- 30

Miscellaneous reach studies, Pecos River- 32

Continuing reconnaissance and evaluation of water resources on the White Sands Missile Range - 32

Community and residential water-supply studies under the Navajo area Indian Health Service Program ----

Irrigation potential of the Ogallala Formation and associated Cretaceous and Jurassic sediments, Northern High Plains, New Mexico

Investigation and analysis of floods for small drainage areas in New Mexico -

Ground-water resources and geology of Harding County, New Mexico -

Water resources of the Mimbres Basin, New Mexico----Water resources of Santa Fe County, New Mexico Effects of highway construction on water supply in parts of Tijeras Canyon, New Mexico- 42

A comprehensive study of the water resources of the lower Rio Grande Valley area, New Mexico - 45

Reconnaissance of water resources available to urban areas, New Mexico

Effects of energy resources development on the hydrogeologic environment of northwestern New Mexico

Mean-annual runoff from streams in New Mexico as related to channel geometry - 
Projects in Progress Fiscal Year 1978 - Concluded

Interpretive hydrologic investigations - Concluded

Hydrologic assessment of the Elephant Butte Irrigation District's well field and evaluation of additional drilling sites in the Mesilla Valley, Dona Ana County, New Mexico

Urban flood-hydrology of Albuquerque area,

New Mexico

Water resources of the Zuni Reservation --_- 52

Hydrologic surveillance of coal-lease areas in northwest New Mexico

Water supply investigations for the U.S. Bureau of Indian Affairs

Hydrologic investigations related to a radioactive waste repository in salt, southeastern New Mexico -- 56

Quality of water monitoring in Chaco River basin in northwestern New Mexico's energy development area -Ground water in the Rio Puerco grazing area -------

A study of aquifers in the Capulin area as a possible supplemental water supply for Raton, New Mexico ----

Hydrologic investigations of the Laguna Pueblo, New Mexico

Hydrologic investigations of the Acoma Pueblo, New Mexico

The effects of energy-related developments in the

San Juan Basin on the ground-water and surface-water systems at Chaco Canyon National Monument --------

Water resources monitoring of coal development in the

San Juan Basin, New Mexico

Publications of the U.S. Geological Survey

Reports of investigations--selected references -

Professional papers - 71

Water-supp1y papers -- 72

Circulars - 73

Hydrologic investigations atlases - 74

Open-file reports of the U.S. Geological Survey ---- 75

Water-resources investigations (WRI) reports of the

U.S. Geological Survey - 78

Other publications

Reports of New Mexico District Fiscal Year 1977 - 80 


\section{Contents - Concluded}

Page

NAWDEX

82

The concept and purpose of NAWDEX

82

The organization of NAWDEX

82

NAWDEX services 


\section{Illustrations}

Page

Figure 1.--Map showing location of offices of the New Mexico District and areas of responsibility

2.--Map showing location of surface-water gaging stations in New Mexico

3.--Map showing areas with many ground-water observation wells in New Mexico

4.--Map showing location of water-quality gaging stations in New Mexico

5.--Map showing location of HUD flood insurance studies in New Mexico

6.--Map showing Rio Grande basin above Fort Quitman, Texas

7.--Map showing location of the Roswell basin in New Mexico

8.--Map showing location of Pecos River and major tributaries in New Mexico

9.--Map showing location of White Sands Missile Range, New Mexico

10.--Map showing location of Navajo Indian Reservation, New Mexico

11.--Map showing location of project area for the Northern High Plains study; New Mexico, Oklahoma, and Texas

12.--Map showing location of Harding County study area, New Mexico

13.--Map showing location of the Mimbres Basin study area, New Mexico

14.--Map showing location of Santa Fe County study area, New Mexico

15.--Map showing location of Tijeras Canyon study area, New Mexico 


\section{Illustrations - Concluded}

Figure 16.--Map showing location of the lower Rio Grande study area, New Mexico

Page

17.--Map showing location of San Juan Basin study area, New Mexico -

18.--Map showing location of the Elephant Butte Irrigation District evaluation study area, New Mexico - 50

19.--Map showing location of the Albuquerque, New Mexico flood-hydrology study area

20.--Map showing location of the Zuni Indian Reservation study area in New Mexico

21.--Map showing location of hydrologic surveillance of coal-1ease area sites in northwestern New Mexico

22.--Map showing location of radioactive waste repository study area and proposed Waste Isolation Pilot

Plant Site near Carlsbad, New Mexico

23. --Map showing location of Chaco River basin study area in northwestern New Mexico --

24.--Map showing location of the Rio Puerco grazing area study in New Mexico

25.--Map showing location of the Capulin ground-water study area in New Mexico --

26.--Map showing location of Laguna Pueblo lands study area, New Mexico

27.--Map showing location of Acoma Pueblo 1ands study area, New Mexico

28.--Map showing location of Chaco Canyon National

Monument study area, New Mexico

29.--Map showing location of study area for coal development expanded monitoring program in New Mexico 
Blank page 


\title{
WATER RESOURCES INVESTIGATIONS OF THE
}

\section{U.S. GEOLOGICAL SURVEY, NEW MEXICO DISTRICT}

\author{
Fiscal Year 1978
}

Compiled by P. L. Soule and D. W. Wilkins

\section{Abstract}

The U.S. Geological Survey's Water Resources Division investigates the occurrence, quantity, quality, distribution, and movement of the Nation's surface and underground waters, and coordinates the federal water-data acquisition activities.

As of April 1978 the District had 36 active projects, 30 reports for release, and answered at least 5,000 requests for water related information.

\section{Introduction}

The U.S. Geological Survey, through its Water Resources Division, investigates the occurrence, quantity, quality, distribution, and movement of the surface and underground waters that comprise the Nation's water resources, and coordinates the Federal water-data acquisition activities.

The mission of the Division is accomplished through programs supported by the U.S. Geological Survey and through programs supported and accomplished in cooperation with other federal and non-federal agencies. These programs involve:

1. Collecting, on a systematic basis, data needed for the continuing determination and evaluation of the quantity, quality, and use of the Nation's water resources. 
2. Conducting analytical and interpretive water-resource appraisals describing the occurrence; availability; and the physical, chemical, and biological characteristics of surface and ground water.

3. Conducting supportive basic and problem-oriented research in hydraulics, hydrology, and related fields of science to improve the scientific basis for investigations and measurement techniques, and to understand hydrologic systems sufficient1y well to predict quantitatively their response to stress either natural or manmade.

4. Disseminating the water data and the results of these investigations and research through reports, maps, computerized information services, and other forms of public releases.

5. Coordinating the activities of federal agencies in the acquisition of water data for streams, lakes, reservoirs, estuaries, and ground waters.

6. Providing scientific and technical assistance in hydrologic fields to other federal, state, and local agencies, to licensees of the Federal Power Commission, and to international agencies on behalf of the Department of State.

"Because of its arid southwest location, New Mexico's water supply is one of its most important and valuable assets and generally is considered the key factor affecting future economic growth and quality of life in New Mexico."1/

1/ U.S. Department of the Interior, Western U.S. Water Plan Study, 1975.

The New Mexico District of the U.S. Geological Survey, Water Resources Division along with other federal and state agencies shares in the responsibility for the appraisal of the quantity, quality, and distribution of surface- and ground-water resources of the State of New Mexico. 
This report contains information concerning the U.S. Geological Survey's water-resources investigations and surveillance programs in New Mexico. The New Mexico District office is located in Albuquerque with subdistrict offices and field headquarters located throughout the State (fig. 1). Requests for information should be addressed as follows:

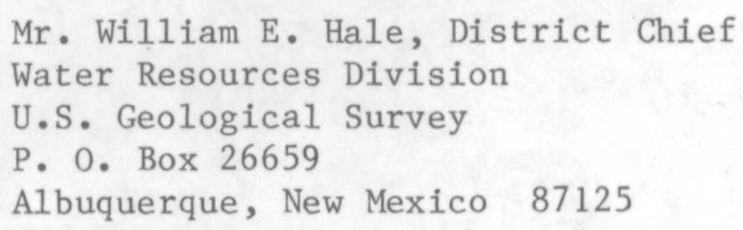

Current District programs encompass the following waterinformation areas:

1. Chemical quality of surface water in New Mexico

2. Chemical quality of ground water in New Mexico

3. Sediment transport in New Mexico streams

4. Surface-water supply

5. Surface-water diversions for irrigation

6. Streamflow characteristics

\author{
High flow \\ Low flow \\ Flood frequency
}

7. Effect of urban development on storm runoff

8. Inundation from floods

9. Effects of ground-water pumping

10. Long-term monitoring of ground-water levels

11. Ground-water and surface-water relationships

12. Consumptive use of phreatophytes

13. Hydrologic impacts of energy development

14. Ground-water supplies

15. Hydrologic impacts of ground-water development 


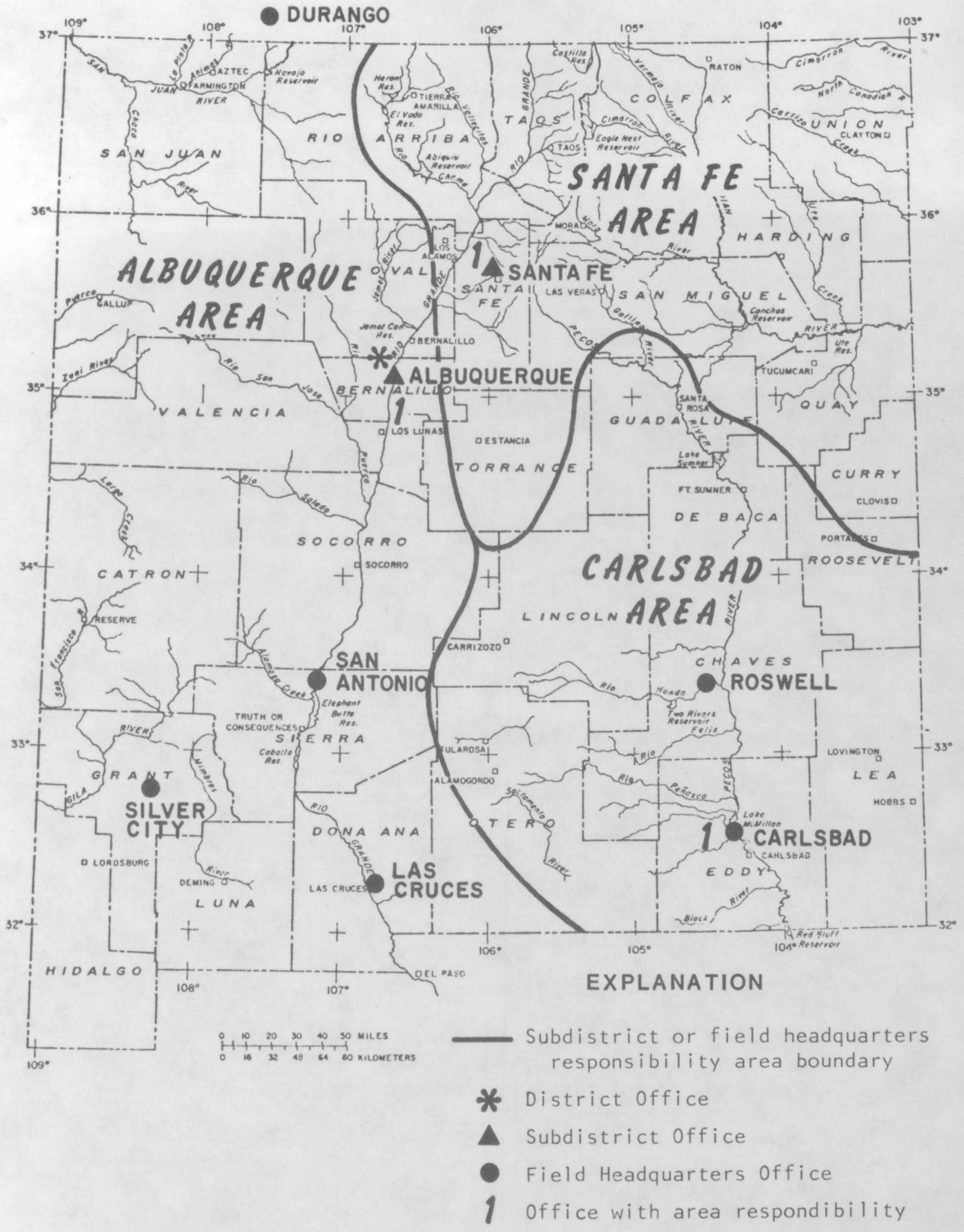

Figure 1.--Location of offices of the New Mexico District and 
As of April 1978, the District had 36 active projects. During the past year the New Mexico District prepared for release 30 reports and answered at least 5,000 requests for water-related information.

The programs of the District are supported by federal funding to the Geological Survey and in cooperation with other federal, state, and local agencies. Agencies cooperating with the U.S. Geological Survey during fiscal year 1978 are:

\section{State and Local}

Albuquerque Metropolitan Arroyo

Flood Control Authority

City of Albuquerque

City of Las Cruces

Costilla Creek Compact Commission

Elephant Butte Irrigation District

New Mexico Bureau of Mines and

Mineral Resources

New Mexico Environmental

Improvement Division

New Mexico Interstate Stream

Commission

New Mexico State Highway

Department

office of New Mexico State

Engineer

Pecos River Commission

Pueblo of Zuni

Rio Grande Compact Commission

\section{Federal}

U.S. Department of Agriculture Forest Service

National Park Service

Soil Conservation Service

U.S. Department of the Army

Army Corps of Engineers

White Sands Missile Range

U.S. Department of Energy

U.S. Department of Housing

and Urban Development

Environmenta1 Protection Agency

U.S. Department of the Interior

Bureau of Indian Affairs

Bureau of Land Management

Bureau of Reclamation 


\section{Hydrologic-data program}

Hydrologic-data stations are maintained by the Geological Survey at selected key locations throughout New Mexico. They constitute a network for obtaining records of stream stage and discharge, reservoir and lake storage, ground-water levels, well and spring discharge, and the quality of surface and ground water (figs. 2, 3, and 4). The Water Resources Division has both a current and historical file of hydrologic data. All data collected are stored in the Geological Survey's National Water Data Storage and Retrieval System (WATSTORE) and are available on request. These data can be retrieved in machine-readable form, as computer-printed tables or graphs, or digital plots. Computer programs are available for statistical analysis of the data and the results of the analyses are available. Local assistance in the acquisition of services or products from WATSTORE can be obtained from the District Chief, Water Resources Division, in Albuquerque. For information on data reports that are published periodically as part of this program see the "Publications of the U.S. Geological Survey" section of this report.

A summary of each data collection program follows. The summary consists of a map showing the location of the hydrologic-data stations, a list of cooperating agencies, a brief description of the programs purpose and scope, and project reports released during the prior fiscal year. 


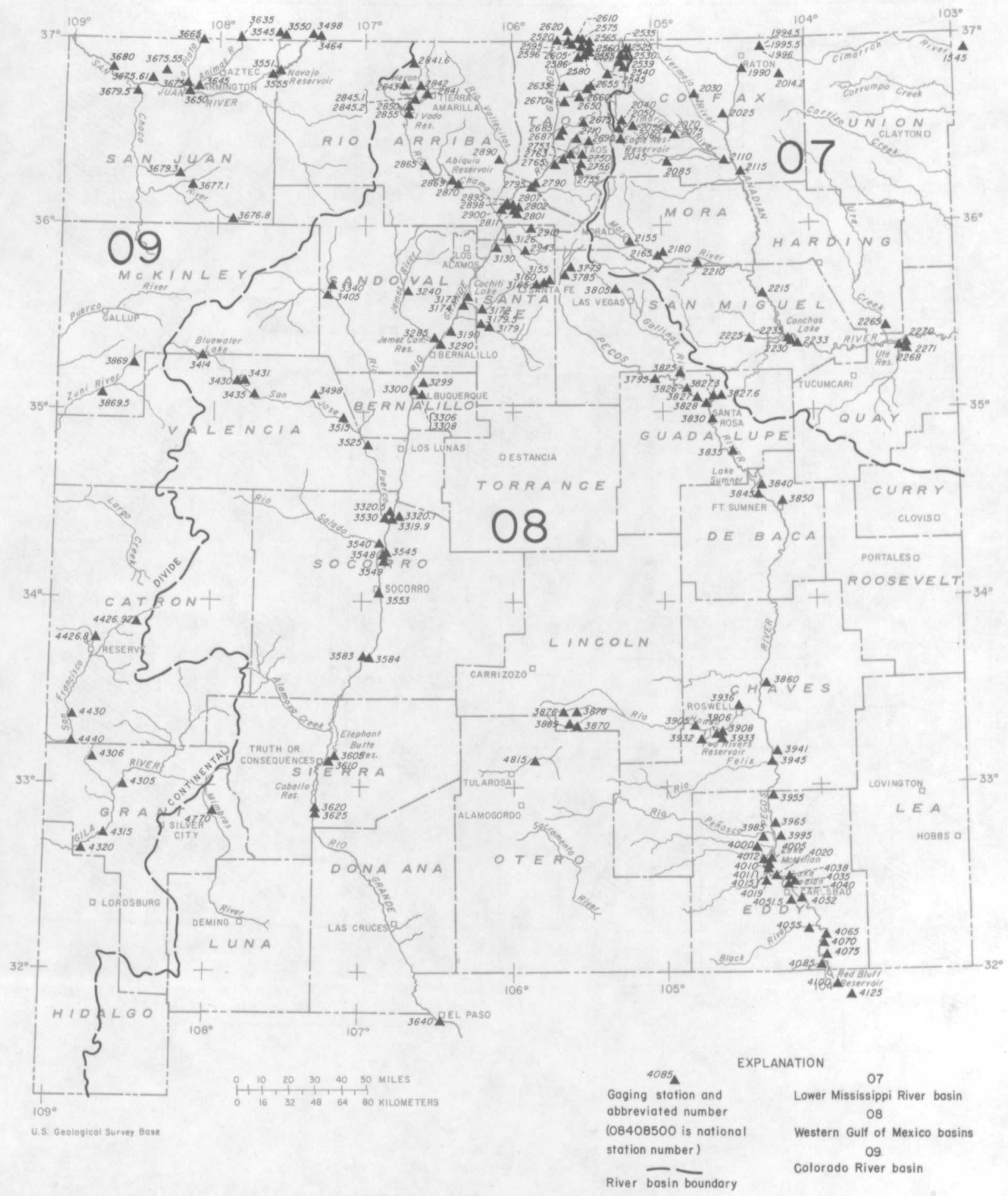

Figure 2.--Location of surface-water gaging stations in New Mexico. 


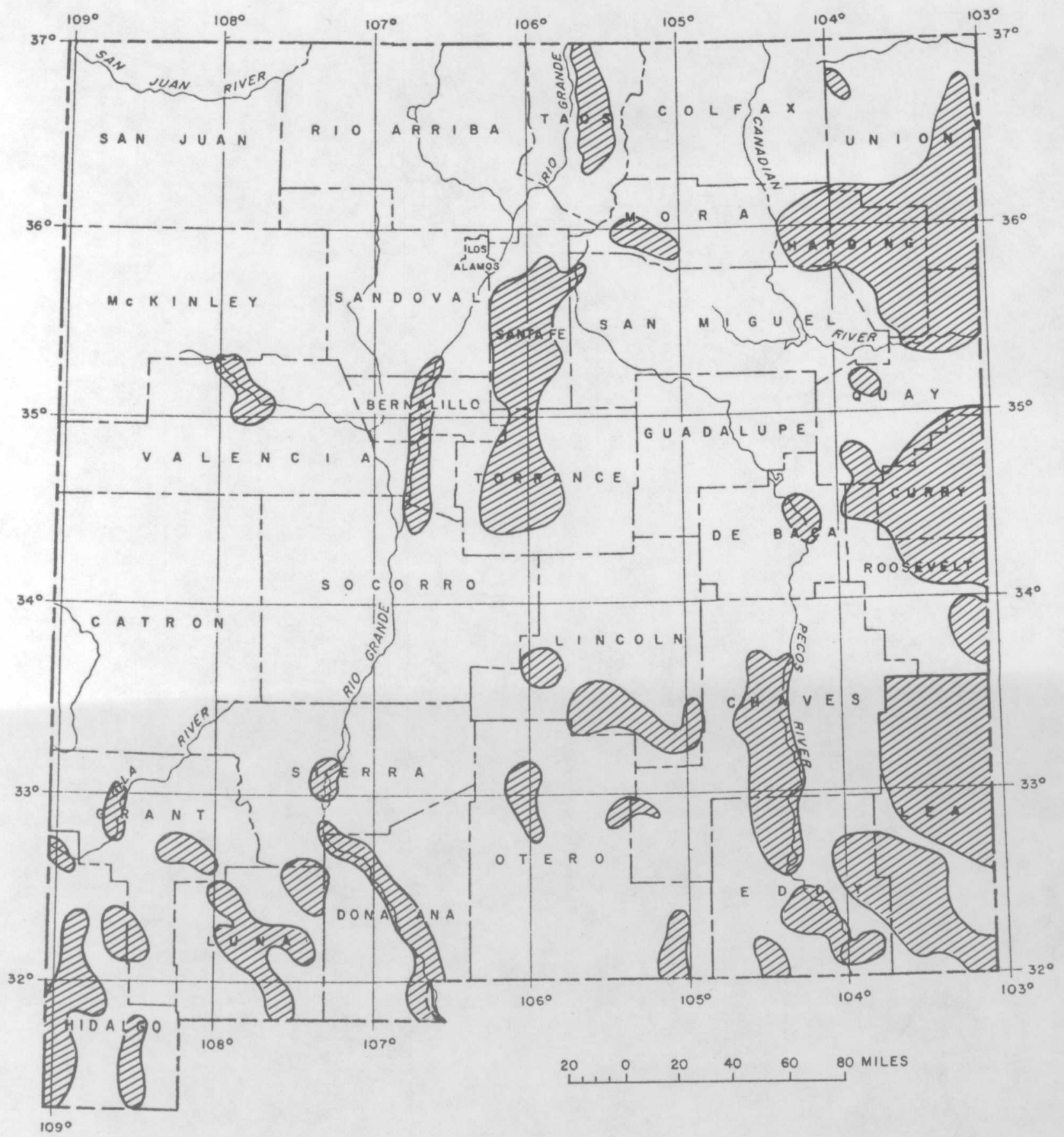

Figure 3.--Areas with many ground-water observation wells in New Mexico 


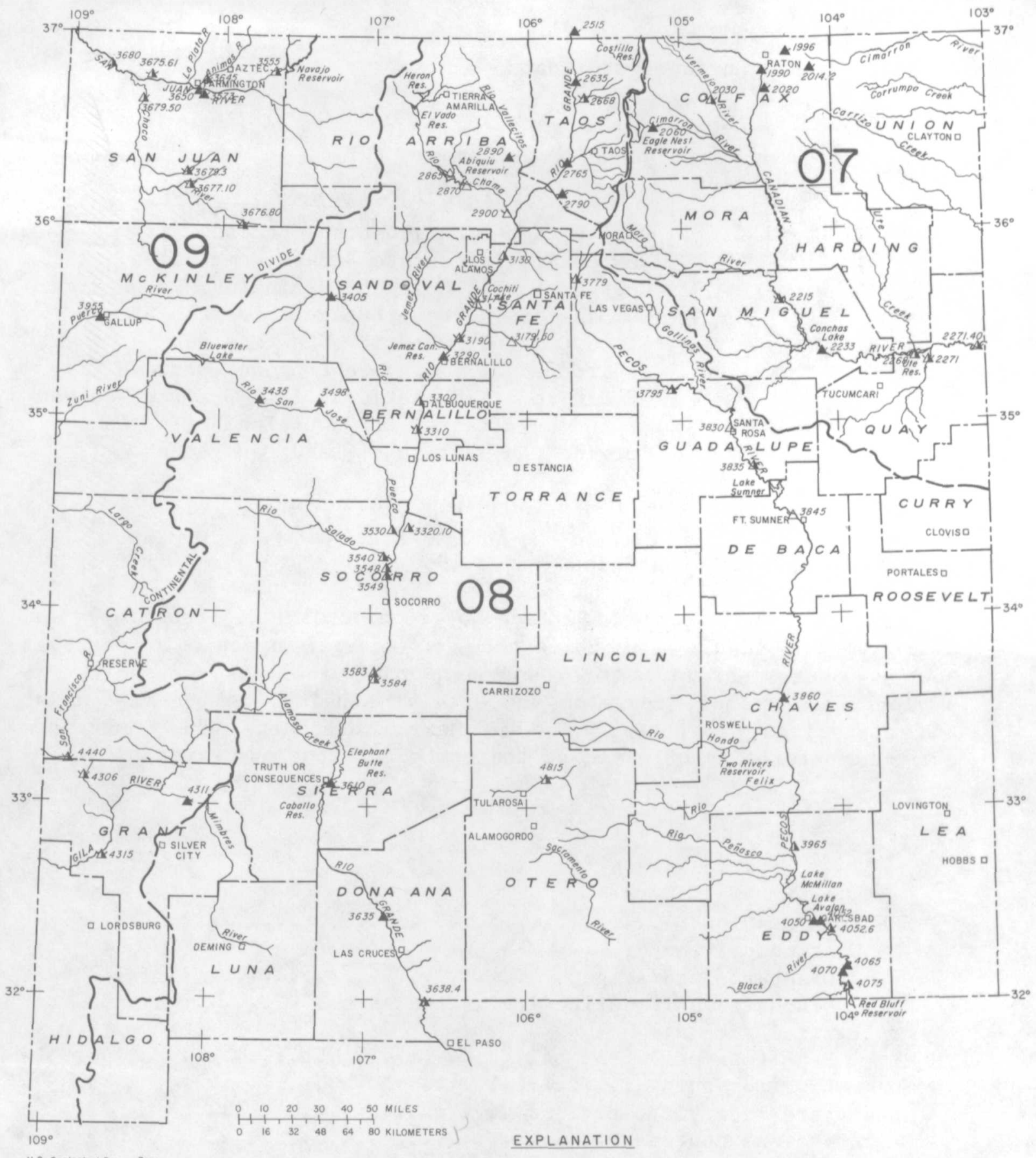

U.S. Geological Survey Base

STATION AND SAMPLING FREQUENCY

Chemical quality: $\Delta$ daily $\mathbf{\Delta}$ other than daily

Suspended sediment: $\Delta$ daily $\quad \Delta$ other than doily

Chemical quality and

Suspended sediment: $\boldsymbol{\Delta}$ both daily $\mathbf{x}$ both other than daily

$\Delta$ daily chemical $\Delta$ daily suspended quality and sediment and other than other than daily

daily suspended chemical quality
BASIN AND STATION NUMBER River basin boundary: Lower Mississippi River basin number: 07 Western Gulf of Mexico basin number: 08 Colorado River basin number: 09 Number by symbol is abbreviated
station number. Complete station
number of example is:

은 227140

Basin no. Station no.

Figure 4.--Location of water-quality gaging stations in New Mexico. 
PROJECT TITLE: Surface-water data

PROJECT NUMBER: NM 00-001

LOCATION: Statewide

COOPERATING AGENCIES: Office of New Mexico State Engineer, New Mexico Interstate Stream Commission, Costilla Creek Compact Commission, Pecos River Commission, Albuquerque Metropolitan Arroyo Flood Control Authority, New Mexico Environmental Improvement Agency, Bureau of Reclammation, National Park Service, Bureau of Indian Affairs, Corps of Engineers, Forest Service, and Bureau of Land Management.

PROJECT CHIEF: Louis P. Denis (505-766-2246)

PERIOD OF PROJECT: Continuous since 1930

Purpose and Scope: Surface-water discharge (streamflow) and stage (water level) are collected for general hydrologic purposes such as assessment of water resources, areal analysis, determination of long-term trends, research and special studies, or for management and operational purposes. In New Mexico discharge and stage data currently are being obtained at the number of stations given below.

\section{Station classification}

Stream stations

Continuous record:

Discharge and stage $\ldots \ldots \ldots \ldots \ldots \ldots \ldots \ldots \ldots \ldots \ldots$

Discharge only during irrigation season $\ldots \ldots \ldots$.

Partial record:

Peak (maximum) flow only $\ldots \ldots \ldots \ldots \ldots \ldots \ldots \ldots$

Low flow only $\ldots \ldots \ldots \ldots \ldots \ldots \ldots \ldots \ldots \ldots \ldots \ldots$

Lake and reservoir stations $\ldots \ldots \ldots \ldots \ldots \ldots \ldots \ldots \ldots$

Stage and contents $\ldots \ldots \ldots \ldots \ldots \ldots \ldots \ldots \ldots \ldots \ldots$

Tota1
Number of

stations

371

187

33

148

3

23

23

394

Al1 stations are shown on the map except partial-record stations that record peak flow only (148), low flow (3), and selected stations operated only during irrigation season (33). 
Reports Published or Released During Fiscal Year 1977: U.S. Geological Survey, 1976, Water Resources Data for New Mexico, Water Year 1975, Section 1 Surface-water Records: U.S. Geological Survey Water-Data Report, NM-75-1, p. 35-262.

U.S. Geological Survey, 1977, Water Resources Data for New Mexico, Water Year 1976: U.S. Geological Survey Water-Data Report NM-76-1, 655 p.

U.S. Geological Survey, 1977, Water Resources Data for New Mexico, Calendar Year 1975, Surface-water Records: New Mexico State Engineer Water-Data Report, 242 p. 
PROJECT TITLE: Ground-water data

LOCATION: Statewide

COOPERATING AGENCIES: Office of New Mexico State Engineer and Corps of Engineers

PROJECT CHIEF: Jim D. Hudson (505-766-2246)

PERIOD OF PROJECT: Continuous since 1925

Purpose and Scope: The purpose of this project is to collect ground-water data to determine short-range changes and long-range trends in ground-water levels, to relate these data to changes in ground-water storage, and to provide the data base necessary for management of the resource. Water levels in wells, discharge of springs and wells, and water-quality data are key parameters for monitoring ground-water trends; however, they must be integrated with other observations and studies of ground-water systems in order to have the fullest meaning and usefulness. A basic network of observation wells is maintained in New Mexico for monitoring fluctuations of water levels. Other wells known as "project wells" are used for specific (generally short-term) studies and, although they are not part of the basic observation-well network, data obtained from them also are available. The number of observation wells and springs currently being measured is given in the following table. (Project wells are not included)

Station classification

Observation we11s :

Levels $\ldots \ldots \ldots \ldots \ldots \ldots \ldots \ldots \ldots \ldots \ldots \ldots \ldots \ldots \ldots \ldots \ldots$

Springs (discharge)
Number of

stations

1,667 5

Locations of individual observation wells are not shown; however, areas of many observation wells are shown on figure 3 . 
Reports Published or Released During Fiscal Year 1977: Hudson, J. D., 1977, Delineated areas of decline in the ground-water reservoir, Portales Valley, Roosevelt County, New Mexico, 1976: New Mexico State Engineer Map R0-20, 1 sheet.

Hudson, J. D., 1977, Delineated areas of decline in the ground-water reservoir in a part of Curry County, New Mexico, 1976: New Mexico State Engineer Map $\mathrm{CH}-17,1$ sheet.

Hudson, J. D., 1977, Delineated areas of decline in the ground-water reservoir in the northern and central part of Lea County, New Mexico, 1976: New Mexico State Engineer Maps LN-19 and LC-19, 2 sheets.

U.S. Geological Survey, 1976, Water Resources Data for New Mexico, Water Year 1975, Section 3 Ground Water Records: U.S. Geological Survey Water-Data Report, NM-75-1, p. 581-598.

U.S. Geological Survey, 1977, Water Resources Data for New Mexico, Water Year 1976: U.S. Geologica1 Survey Water-Data Report NM-76-1, p. 577-602. 
PROJECT TITLE: Chemical quality and Biological water data

LOCATION: Statewide

COOPERATING AGENCIES: Office of New Mexico State Engineer,

New Mexico Interstate Stream Commission, Pecos

River Commission, and Bureau of Reclamation

PROJECT CHIEF: Richard L. Lepp (505-766-2246)

PERIOD OF PROJECT: Continuous since 1937

Purpose and Scope: The purpose of the chemical and biological quality water program is to provide for the collection analysis, storage, and publication of water quality data from a network of surface- and ground-water sites in New Mexico.

Chemical and biological quality water data are obtained at 52 regular surface-water stations and also at 10 other surface-water sites where discharge and stage would not be measured routinely. These stations are used to monitor the quality of surface water in New Mexico. Some of these stations also are part of the Geological Survey nationwide network known as the National Stream Quality Accounting Network (NASQAN), which is used to detect nationwide trends in water quality. The types of data determined at these sites are given in the following table. Inasmuch as several types of data may be determined at a particular site and not all types of data are determined at each site, the numbers given in the following table will not equal the total number of sites given earlier.

Data classification

Physical data:

Water temperature $\ldots \ldots \ldots \ldots \ldots \ldots \ldots \ldots \ldots \ldots \ldots$

Specific conductance $\ldots \ldots \ldots \ldots \ldots \ldots \ldots \ldots \ldots \ldots \ldots$

$\mathrm{pH}$

Chemical data:

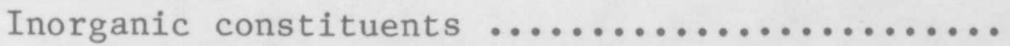

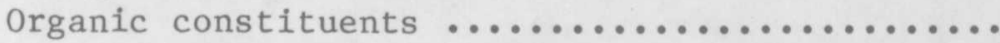

Pesticides and organic carbon $\ldots \ldots \ldots \ldots \ldots \ldots$

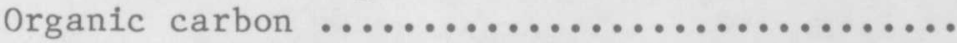

Radiochemical data $\ldots \ldots \ldots \ldots \ldots \ldots \ldots \ldots \ldots \ldots \ldots \ldots$

Biological data
Number of sites

Chemical quality water data for ground water was obtained in conjunction with project activities. (In 1976 approximately 300 sites were sampled). 
Reports Published or Released During Fiscal Year 1977: U.S. Geological Survey, 1976, Water Resources Data for New Mexico, Water Year 1975, Section 2 Water Quality Records: U.S. Geological Survey Water-Data Report, NM-75-1, p. 263-579.

U.S. Geological Survey, 1977, Water Resources Data for New Mexico, Calendar Year 1975, Water-Quality Records: New Mexico State Engineer Water-Data Report, $345 \mathrm{p}$.

U.S. Geological Survey, 1977, Water Resources Data for New Mexico, Water Year 1976: U.S. Geological Survey Water-Data Report NM-76-1, $655 \mathrm{p}$. 
PROJECT TITLE: Sediment data

LOCATION: Statewide

COOPERATING AGENCIES: Office of New Mexico State Engineer, New Mexico Interstate Stream Commission, National Park Service, and Corps of Engineers

PROJECT CHIEF: David E. Funderburg (505-766-2246)

PERIOD OF PROJECT: Continuous since 1937

Purpose and Scope: This project determines the load, size, and nature of sediment carried in New Mexico streams. Data is collected to provide information for the evaluation of sources and sinks of sediment, effects of changing land use, effects of water management on channel stability, and regional base line conditions.

As of March 1978 there are 45 sediment stations in New Mexico. At 14 of these sites a continuous record of sediment load is computed from data provided by local observers and (or) automatic pumping samplers which collect at least a daily sample and samples more frequently during high-water runoff periods. The remaining sites are sampled intermittently and during peak runoff periods.

Reports Published or Released During Fiscal Year 1977: U.S. Geological Survey, 1976, Water Resources Data for New Mexico, Water Year 1975, Section 2 Water Quality Records: U.S. Geological Survey Water-Data Report NM-75-1, p. 263-579.

U.S. Geologica1 Survey, 1977, Water Resources Data for New Mexico, Calendar Year 1975, Water-Quality Records: New Mexico State Engineer Water-Data Report, 345 p.

U.S. Geological Survey, 1977, Water Resources Data for New Mexico, Water Year 1976: U.S. Geological Survey Water-Data Report NM-76-1, 655 p.

Funderburg, D. E., 1977, Trap Efficiency Investigation, Bernalillo Floodwater Retarding Reservoir No. 1 (Piedra Lisa Arroyo) near Bernalillo, New Mexico, Water Years 1956-1974: U.S. Geological Survey Open-File Report 77-261, 43 p.

Funderburg, D. E., and Roybal, F. E., 1977, Sediment-Trap Efficiency of Tortugas Arroyo near Las Cruces, New Mexico, Water Years 1963-1974: U.S. Geological Survey Open-File Report 77-586, 56 p. 
Hydrologic investigations include areal resource appraisals, data collection other than part of the hydrologic-data program, and research activities. The New Mexico District has 31 interpretive hydrologic investigations in progress.

Summaries of each of the investigations follows and consists of a map showing the location of investigation (except for statewide studies) and a brief statement of the problem objectives, and reports released during the prior fiscal year. 
COOPERATING AGENCY: Department of Housing and Urban Development

PROJECT CHIEF: Louis P. Denis

PERIOD OF PROJECT: November 1976 to March 1979

Problem.--The communities of Belen, Grants, and Milan (fig. 5) have made application and are presently covered under the emergency provisions of the Flood Insurance Act of 1968 and the Flood Disaster Protection Act of 1973. A detailed flood insurance study is required to convert coverage to the regular program of flood insurance by the Federal Insurance Administration.

Objectives.--To study flood prone areas in and around the communities of Belen, Grants, and Milan both in detail and by approximate methods as applicable. Flood profiles will be developed for 10-, 50-, 100-, and 500-year floods. The 100-year flood boundary will be delineated and a floodway analysis done for appropriate channels.

PROJECT TITLE: Duties for the Rio Grande Compact Commission

COOPERATING AGENCY: Rio Grande Compact Commission

PROJECT CHIEF : Pat L. Soule

PERIOD OF PROJECT: Continuous since February 1948

Problem.--The Rio Grande Compact Commission is composed of representatives of the states of Colorado, New Mexico, and Texas. The administration of the compact requires that streamflow and water storage facts for that area of the Rio Grande basin upstream from Fort Quitman, Texas (fig. 6) be collected, compiled, correlated, and presented to the commission.

Objectives.--Perform duties of secretary as outlined in the rules and regulations of the Rio Grande Compact Commission. Principal duty is compilation of streamflow and storage data for publication in the annual report of the commission.

Reports published or released during fiscal year 1977.--U.S. Geological Survey, 1977, report of the Rio Grande Compact Commission, 1976: Rio Grande Compact Commission. 


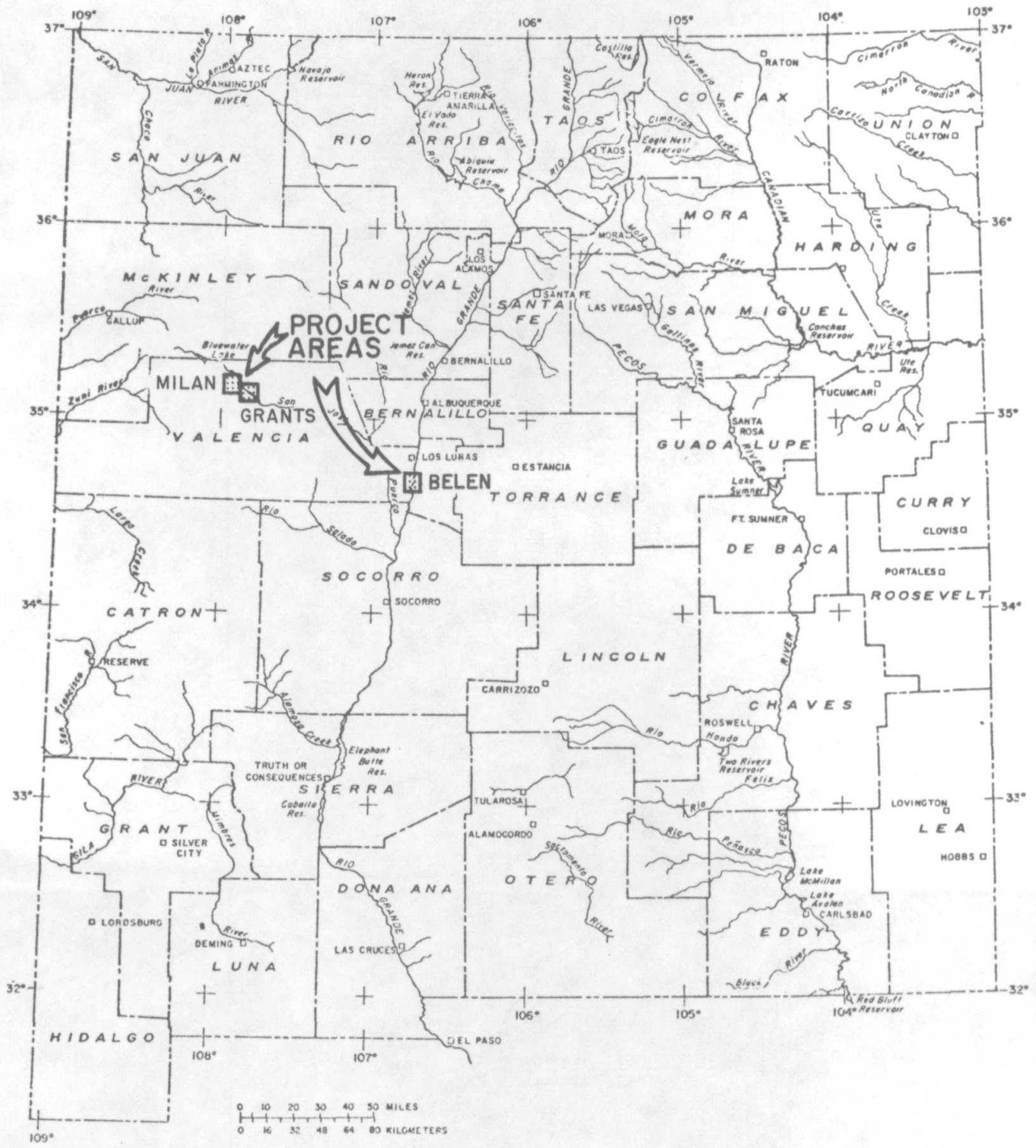

Figure 5.--Location of HUD flood insurance studies in New Mexico. 


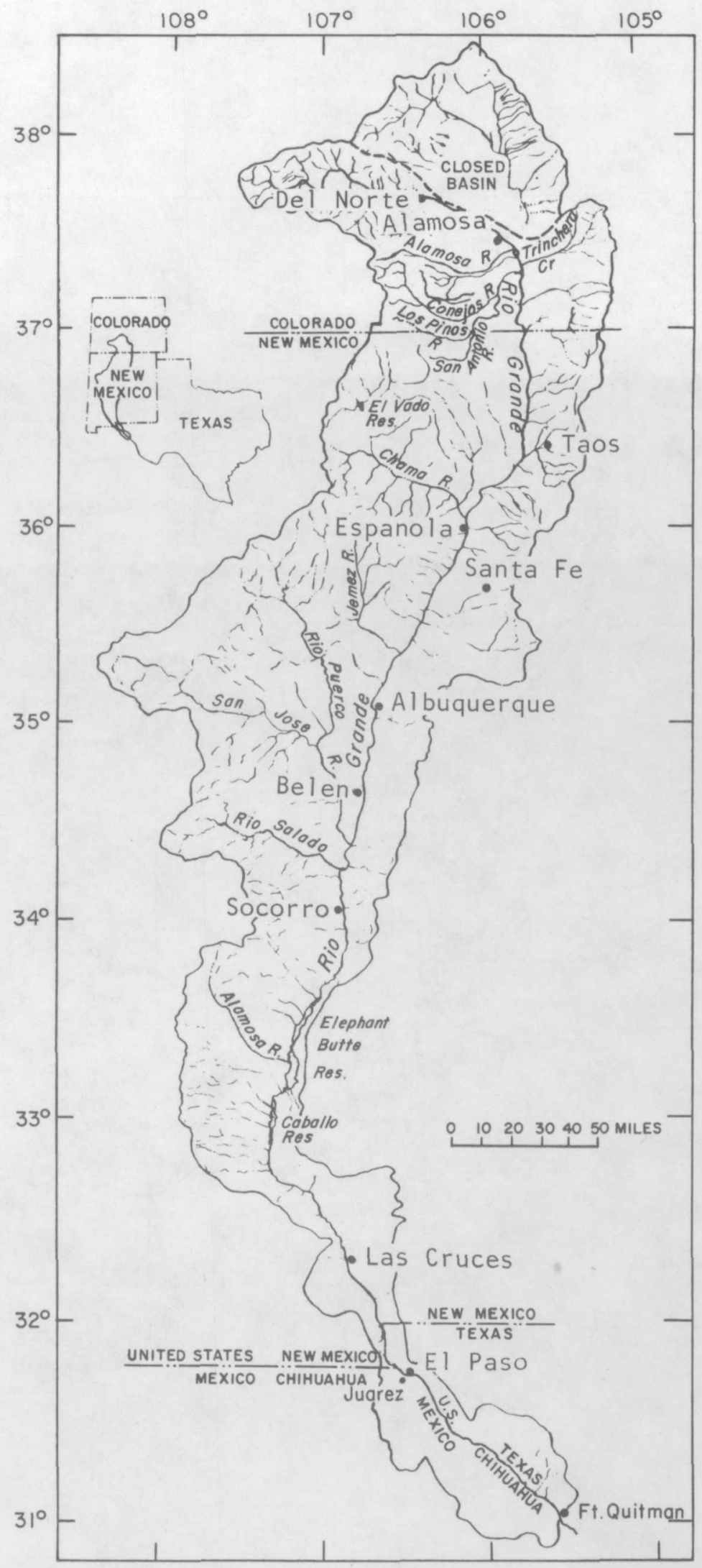

Figure 6.--Rio Grande basin above Fort Quitman, Texas. 
PROJECT TITLE:

Miscellaneous activities under the State Engineer Program

COOPERATING AGENCY: New Mexico State Engineer

PROJECT CHIEF: Walter A. Mourant

PERIOD OF PROJECT: Continuous since January 1960

Problem.--Many letters, telephone contacts, and personal interviews are received by the District from the public on various aspects of the water resources and geology of the State. Occasionally requests are received from the Office of the State Engineer for the compilation of specific data for which no project exists. Funds for specific projects are often exhausted before the resulting report is properly revised and processed for publication.

Objectives.--To make spot reconnaissance studies, letter and telephone reports on inquiries, and compilations of specific data. To revise reports for publication, including those for other agencies, for which funds have been exhausted but which are of advantage to the State to publish. 
PROJECT TITLE:

A quantitative analysis of the ground-water system in the Roswell basin, Chaves and Eddy Counties, New Mexico

COOPERATING AGENCY: New Mexico State Engineer

PROJECT CHIEF: George E. Welder

PERIOD OF PROJECT: Continuous since July 1962

Problem.--In parts of the Roswell basin (fig. 7) development of ground water for agricultural, municipal, and industrial use has caused large head losses. The drop in head is causing movement of saline water into freshwater aquifers and a reduction in quantity and quality of low flow in the Pecos River, an interstate stream. The ground-water supplies in the basin need to be defined.

Objectives.--Define the ground-water supplies in the basin. Study the hydrologic environment in the Roswell basin and determine quantitatively the hydrologic stresses and hydraulic properties of the system so as to define the optimum yield of water from the system.

Reports published or released during fiscal year 1977.-Welder, G. E., 1977, Map showing altitude and configuration of the water level in the "shallow aquifer," January 1964, Roswell basin, Chaves and Eddy Counties, New Mexico: U.S. Geological Survey Open-File Map 77-506.

Welder, G. E., 1977, Map showing altitude and configuration of the water level in the "shallow aquifer," January 1975, Roswell basin, Chaves and Eddy Counties, New Mexico: U.S. Geological Survey Open-File Map 77-505.

PROJECT TItLE: New Mexico District Data Bank

COOPERATING AGENCY: New Mexico State Engineer

PROJECT CHIEF: Douglas R. Posson

PERIOD OF PROJECT: Continuous since November 1970

Problem.--Ground-water records collected during past years by the District are stored in filing cabinets by counties. Data retrieval is done by manual searches.

Objectives.--This project proposes to process all past ground-water records for inclusion in a data bank. The type of data available will be known and retrieved as needed. 


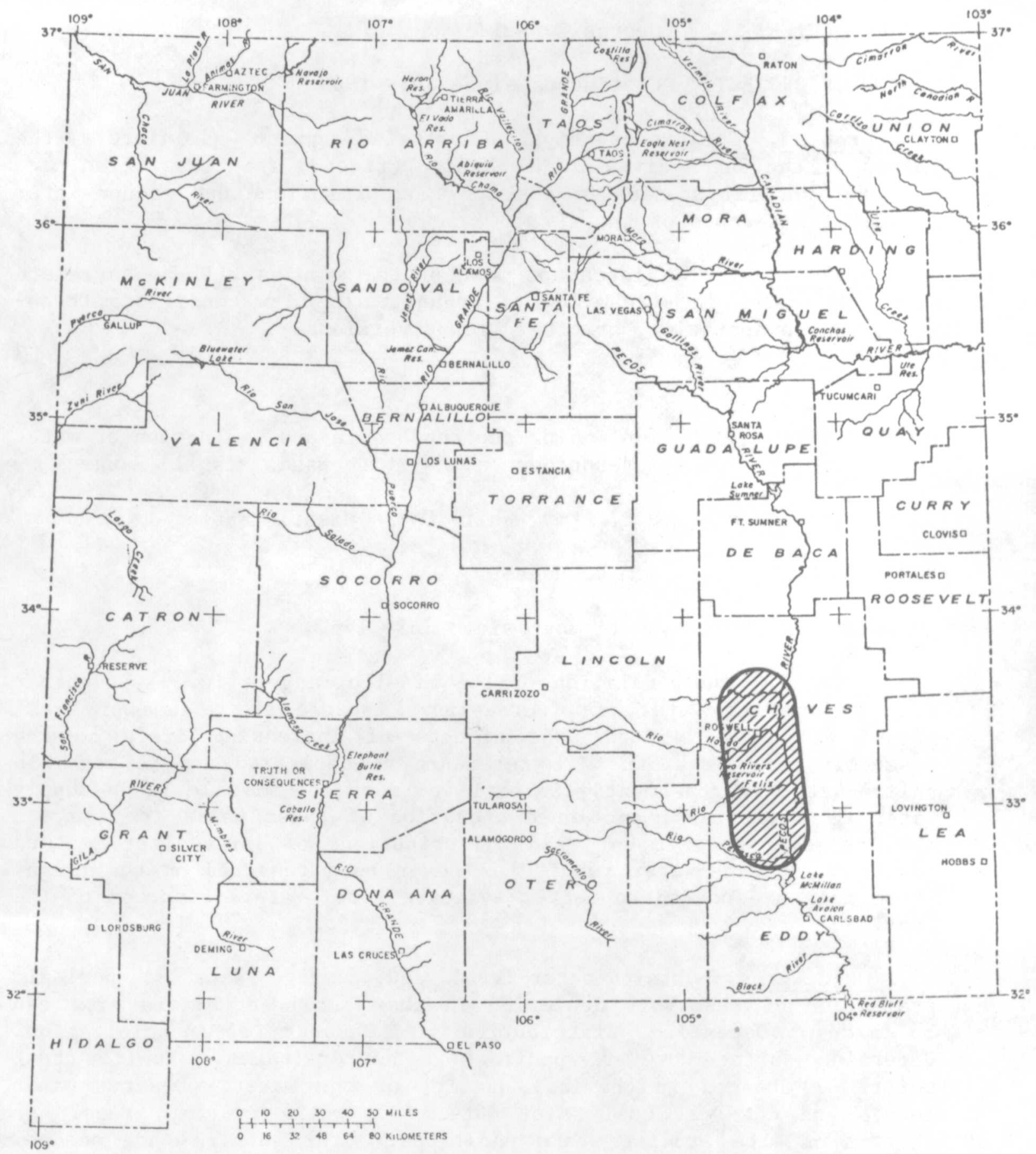

Figure 7.---Location of the Roswell basin in New Mexico. 
PROJECT TITLE: Miscellaneous reach studies, Pecos River

COOPERATING AGENCY: Pecos River Commission

PROJECT CHIEF: George E. Welder

PERIOD OF PROJECT: Continuous since July 1969

Problem.--The Pecos River Commission, which administers the waters of the Pecos River in New Mexico (fig. 8) and Texas often have need for special studies of the relation of surface and ground water in specific reaches of the river.

Objectives.--The intent of most of the studies will be to relate gains or losses in streamflow to ground-water flow conditions, transpiration, evaporation, or other flow diversions.

PROJECT TITLE: Continuing reconnaissance and evaluation of water resources on the White Sands Missile Range

COOPERATING AGENCY: U.S. Army, White Sands Missile Range

PROJECT CHIEF: Jim D. Hudson

PERIOD OF PROJECT: Continuous since July 1960

Problem.--The population of the missile range (fig. 9), together with the use of water, is increasing. Because the volume of fresh ground water is limited, the effects of increasing draft on the reservoir must be known with reference to depletion and to possible saline-water encroachment. Several wells on the missile range supply water to camp areas; continued operation of these wells is vital to the range. The amount and distribution of precipitation and resultant surface-water runoff has never been measured on the range. These data are needed to better evaluate total water resources of the area.

Objectives.--Obtain water-level and pumpage data so periodic evaluation of reservoir depletion in the post headquarters area can be made. Determine distribution and amount of precipitation. Determine surface- water runoff in major drainages. Monitor test wells for changes in chemical quality of the water. Observe water levels and chemical quality of water from wells in camp areas. Do short-term site studies where additional water supplies are needed. Evaluate approaches for economical recovery of the maximum available freshwater.

Reports published or released during fiscal year 1977.--

Cruz, R. R., 1977, Annual Water Resources Review, White Sands Missile Range, 1976-- a basic-data report: U.S. Geological Survey Open-File Report 77-330, 27 p., 7 figs. 


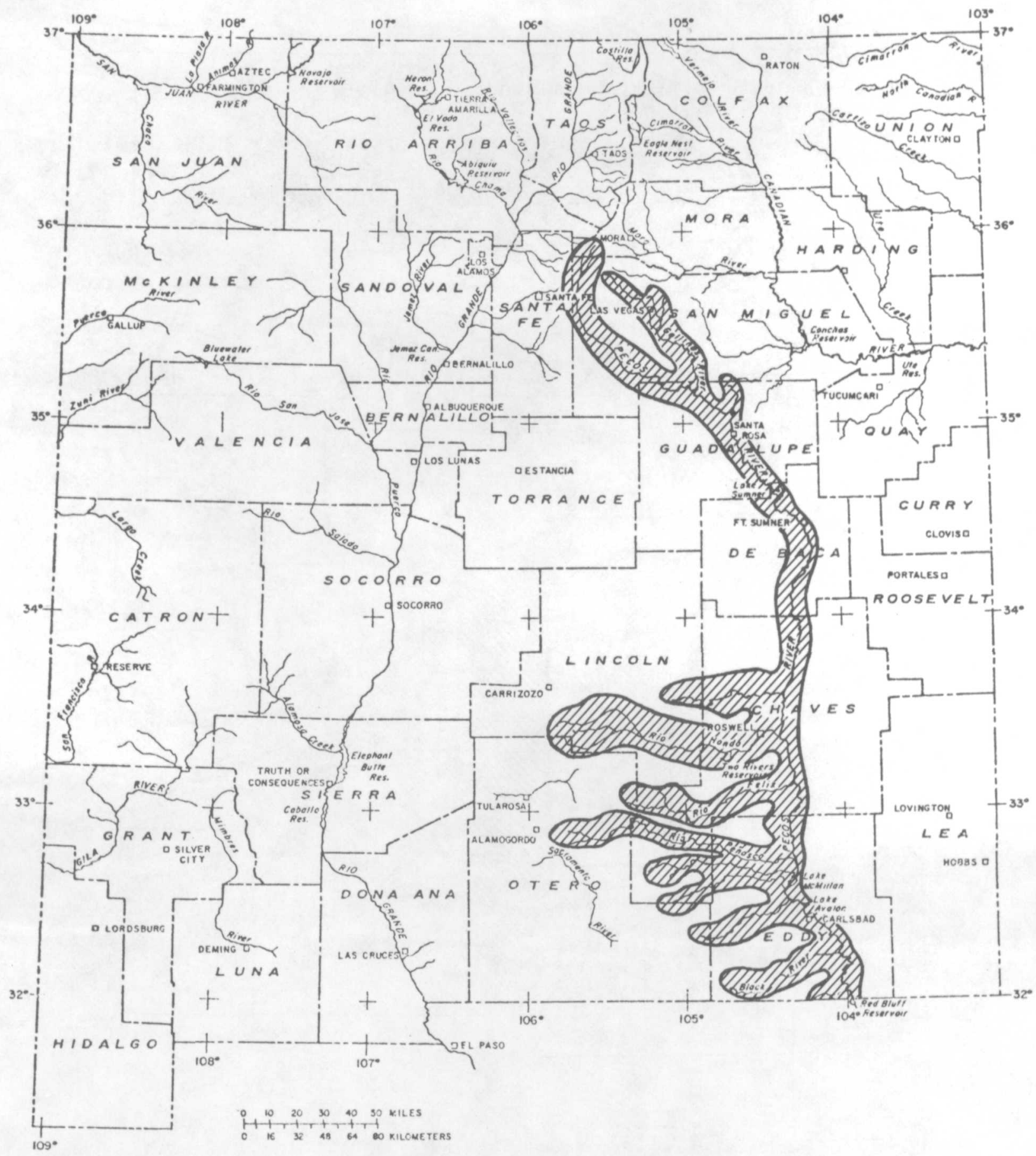

Figure 8.--Location of Pecos River and major tributaries in New Mexico. 


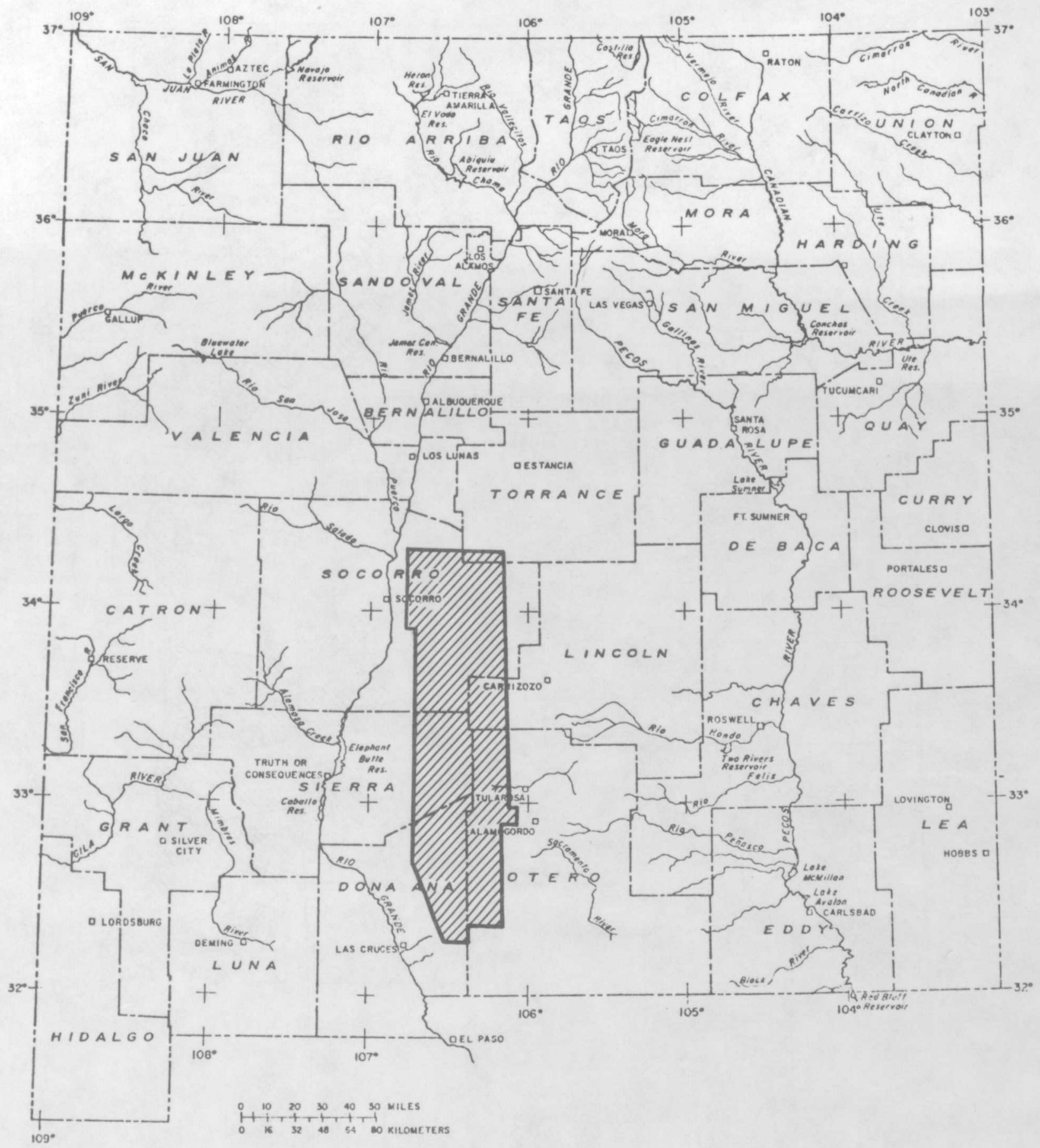

Figure 9.--Location of White Sands Missle Range, New Mexico. 
PROJECT TITLE:

Community and residential water-supply studies under the Navajo area Indian Health Service Program

COOPERATING AGENCY: U.S. Public Health Service, HEW

PROJECT CHIEF: William E. Hale

PERIOD OF PROJECT: Continuous since August 1974

Problem.--The Navajo area Indian Health Service, Public Health Service, Department of Health, Education, and Welfare is responsible for residential and community water supplies on the Navajo Indian Reservation (fig. 10) and at several sites off the reservation where Indians reside either as isolated families or in small communities. The area is geologically and hydrologically complex. Much of the ground water is saline or contains undesirable constituents. In certain locales, wells more than 3,000 feet deep are needed. Yields of wells are commonly meager. The Public Health Service is planning to install modern water-supply systems in communities and to build rural water-supply systems to supply domestic water to rural dwellings. The Public Health Service is requesting that the Geological Survey determine the feasibility of water-supply developments at various sites where water-supply systems are proposed.

Objectives.--Studies will be made of the geology and hydrology of sites on and off the Navajo Reservation to determine if a ground-water supply of suitable quantity and quality can be obtained. If supplies are not available then an attempt will be made to locate a water source within a few miles radius of the site. The Public Health Service will be assisted in planning rural and community water-supply systems. 


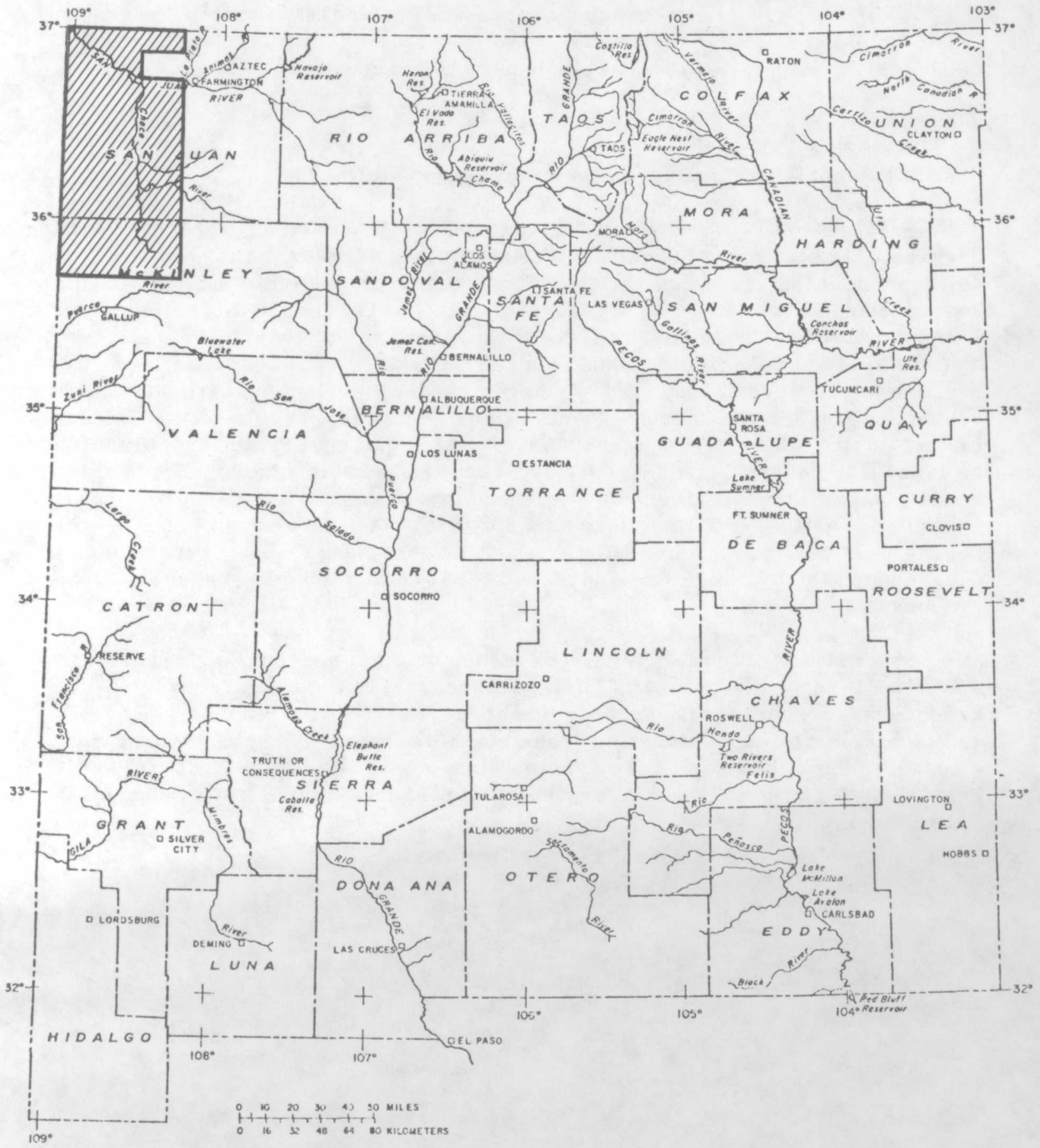

Figure 10.--Location of Navajo Indian Reservation, New Mexico. 
PROJECT TITLE:

Irrigation potential of the Ogallala Formation and associated Cretaceous and Jurassic sediments, Northern High Plains, New Mexico

COOPERATING AGENCY: New Mexico State Engineer

PROJECT CHIEF: $\quad$ Eric G. Lappala

PERIOD OF PROJECT: August 1968 to September 1978

(Completed except for report)

Problem.--Present1y more than 200 wells are pumped for irrigation in the project area (fig. 11). Much of the pumped water is from the Ogallala Formation, although in places large yields are obtained from underlying sandstone of Cretaceous, or possibly, Jurassic age. Accurate information on the saturated thickness of the Ogallala Formation, and a better knowledge of the underlying sandstones is needed to aid in the administration of the waters of the State. A better understanding of the potential for future development of areas not irrigated is needed.

Objectives.--To assess the ground-water resources of the high plains in New Mexico and determine the potential for irrigation development.

PROJECT TITLE: Investigation and analysis of floods for sma11 drainage areas in New Mexico

COOPERATING AGENCY: New Mexico Highway Department

PROJECT CHIEF: Richard P. Thomas

PERIOD OF PROJECT: August 1966 to June 1979

Problem.--The State Highway Department needs data on the frequency and magnitude of floods to better design highway drainage structures.

Objectives.--To collect and analyze hydrologic data which can be used in the design of highway drainage structures. To relate the magnitude and frequency of flood data for drainage areas of less than 15 square miles to basin parameters easily measured by the State Highway Department. 


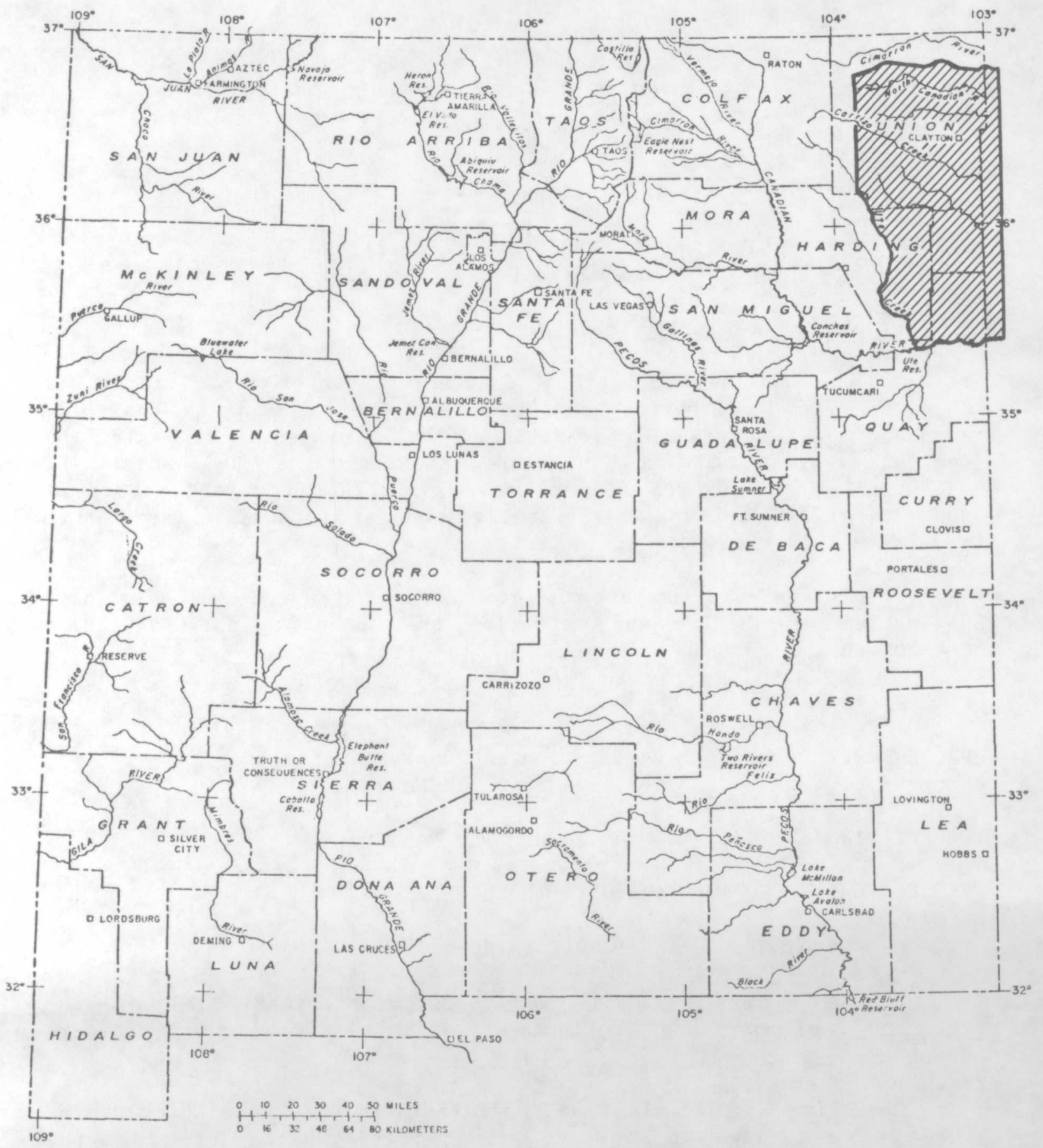

Figure 11.--Location of project area for the Northern High Plains study; New Mexico, Oklahoma, and Texas. 
PROJECT TITLE:

Ground-water resources and geology of Harding County, New Mexico

COOPERATING AGENCY: New Mexico Bureau of Mines and Mineral Resources

PROJECT CHIEF: $\quad$ R. G. Roybal

PERIOD OF PROJECT: October 1966 to September 1978

Problem.- -No previous work has been done on ground-water studies in the county (fig. 12). Irrigation and stock-water supplies are now being sought in the county and ground-water information is needed to develop adequate supplies.

Objectives.--To determine the general availability and quality of ground water in the county; to determine the principal aquifers, their areal extent, and areas of recharge and discharge.

PROJECT TITLE: Water resources of the Mimbres Basin, New Mexico

COOPERATING AGENCY: New Mexico State Engineer

PROJECT CHIEF: John S. McLean

PERIOD OF PROJECT: July 1971 to September 1980

Problem.--Additional data on the water resources of the Mimbres Basin (fig. 13) are needed for administration of available water. Much of the area is irrigated; water levels in the alluvial aquifer are declining; 3,379 square miles of the 4,410 square miles in the basin have been closed to further ground-water development.

Objectives.-To collect and analyze quantitative data on the extent and hydrologic properties of aquifers so that predictions of long-term effects of ground-water withdrawals can be made.

Reports published or released during fiscal year 1977.-McLean, J. S., 1977, Hydrologic maps and data in the Mimbres Basin, New Mexico: U.S. Geological Survey Open-File Report 77-314, 531 p., 8 figs. 


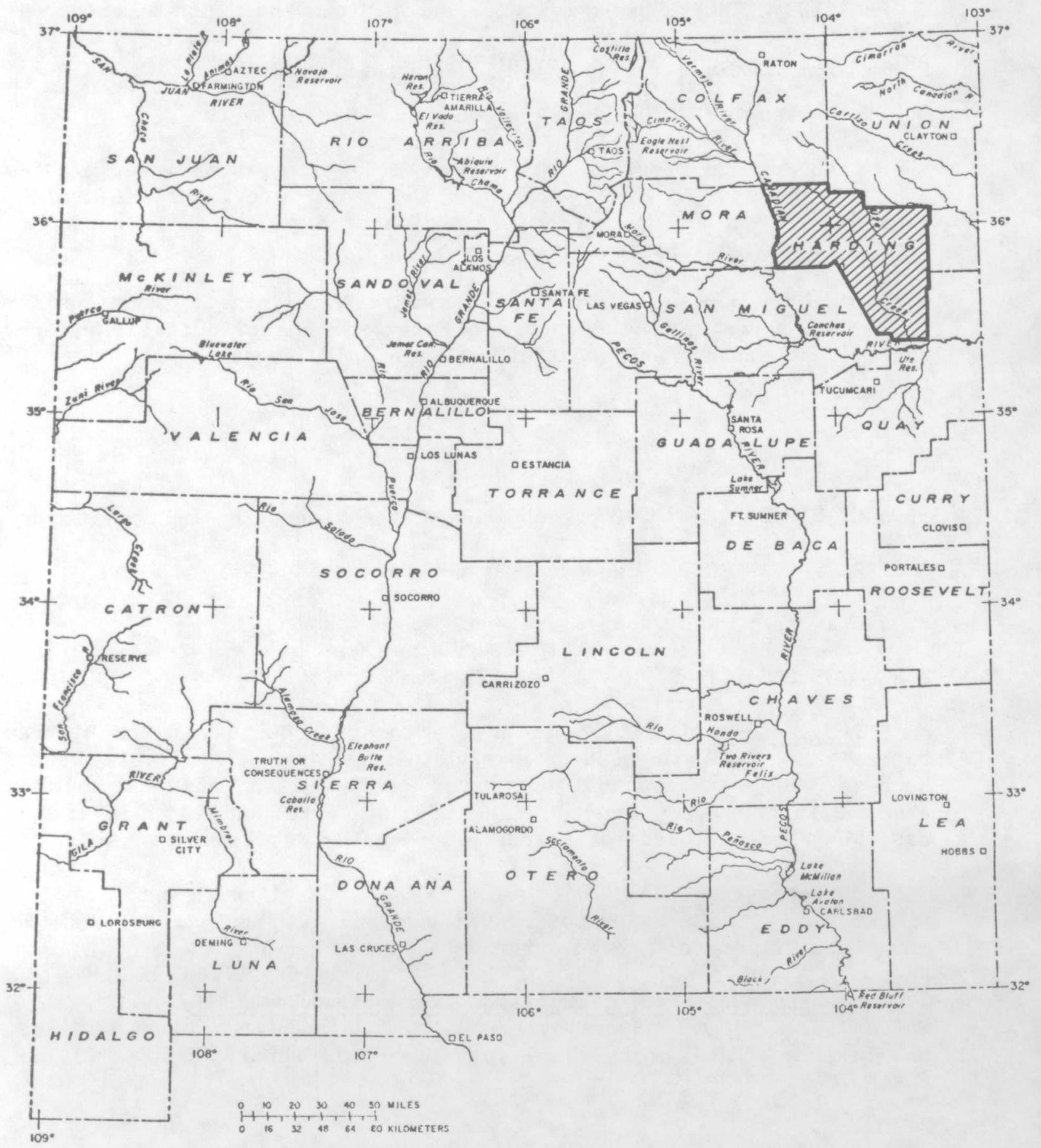

Figure 12.--Location of Harding County study area, New Mexico. 


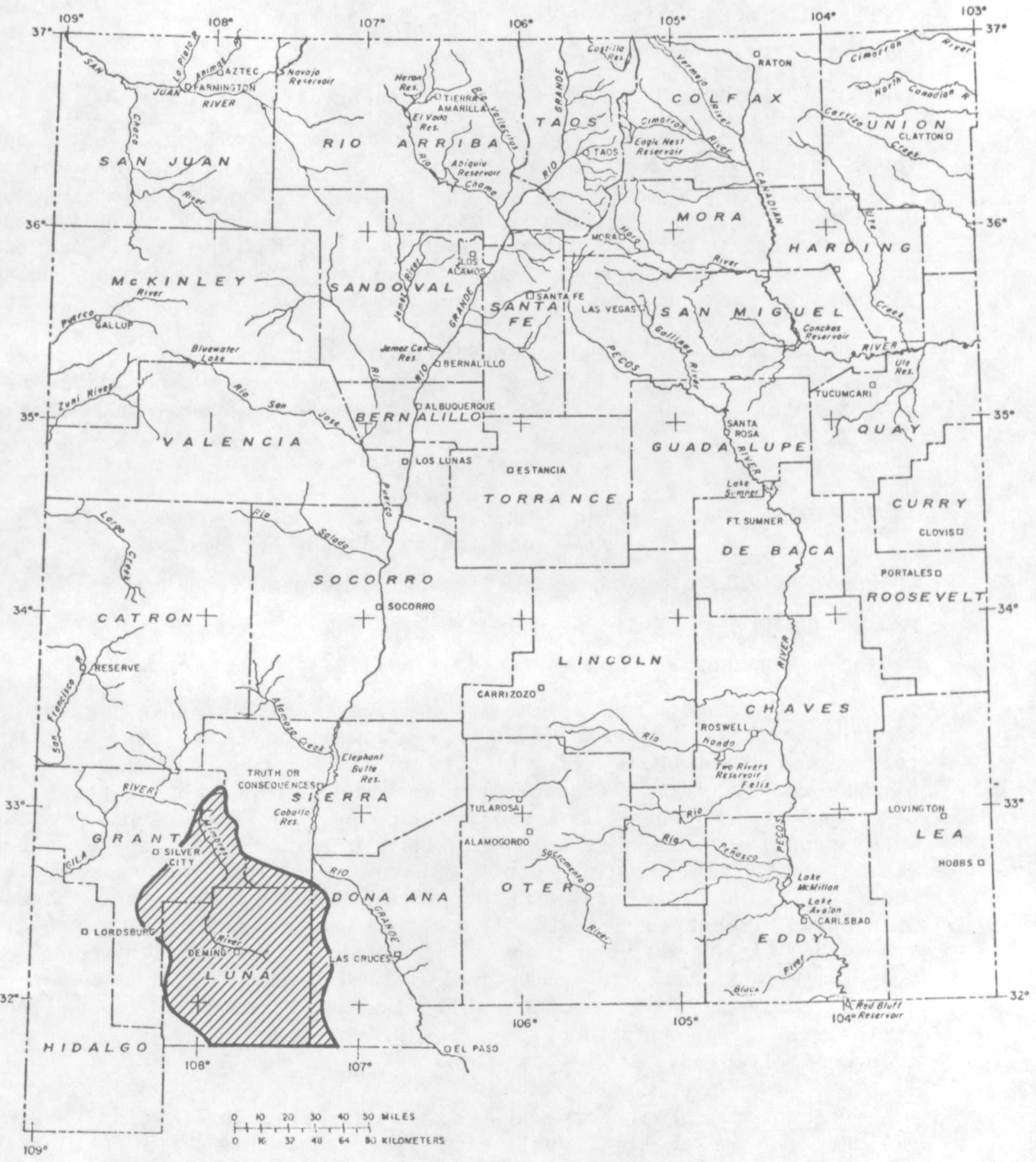

Figure 13.--Location of Mimbres Basin study area, New Mexico. 
COOPERATING AGENCY: New Mexico State Engineer

PROJECT CHIEF :

Walter A. Mourant

PERIOD OF PROJECT: November 1971 to January 1981

Problem.--Several land development companies have purchased large tracts of land in Santa Fe County (fig. 14) and have made plans for community developments. Water supply may be a problem in the development of these communities. A study of the quantity and chemical quality of the water resources of the county is needed for the use of those concerned with water supply, whether for household, community, stock, irrigation, or industrial use.

Objectives.--To obtain geohydrologic data and evaluate aquife yields, chemical quality of water, relationships between surface and ground water, and the effects of water-use developments in Santa $\mathrm{Fe}$ County.

PROJECT TITLE:

Effects of highway construction on water supply in parts of Tijeras Canyon, New Mexico

COOPERATING AGENCY: New Mexico Highway Department

PROJECT CHIEF :

Jim D. Hudson

PERIOD OF PROJECT: June 1972 to March 1979

Problem.--Water supplies may be adversely affected along a 15-mile reach of highway I-40 in Tijeras Canyon (fig. 15), adjacent to the eastern boundary of the city of Albuquerque, as a result of highway construction. Considerable rock needs to be moved; this will be loosened by means of explosive charges of varying sizes. The water-supply situation is not well known in this mountainous area but usually only small water supplies have been developed from wells. Some of the supplies are probably drawn from perched water systems. Opening of fractures beneath the perched water systems might result from the explosions and cause increased drainage. Permanent or temporary impairment to individual well supplies might also occur from loosening of rock in the well bore as a result of shock from explosives. In addition supplies drawn from springs might be adversely affected.

Objectives.--To observe ground-water levels, well yields, spring yields, and the chemical quality of water along the path of highway construction, before, during, and after construction in order to determine if construction work has affected aquifer conditions or individual water sources.

Reports published or released during fiscal year 1977: Hudson, J. D., 1978, A compilation of hydrologic data before and during highway construction in parts of Tijeras Canyon, New Mexico, 1972-1977: U.S. Geological Survey Open-File Report 78-238, 73 p., 5 figs. 


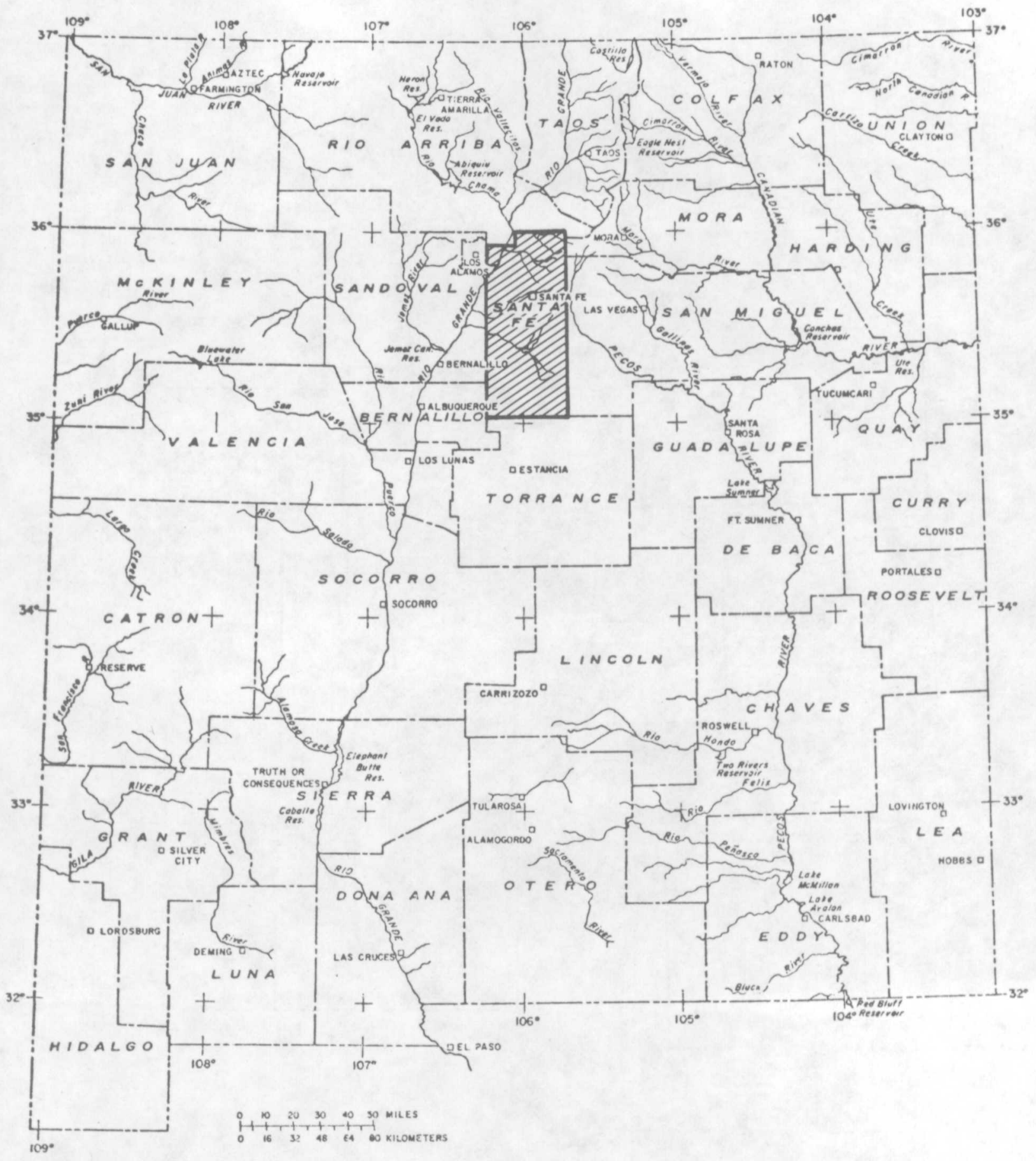

Figure 14.--Location of Santa Fe County study area, New Mexico. 


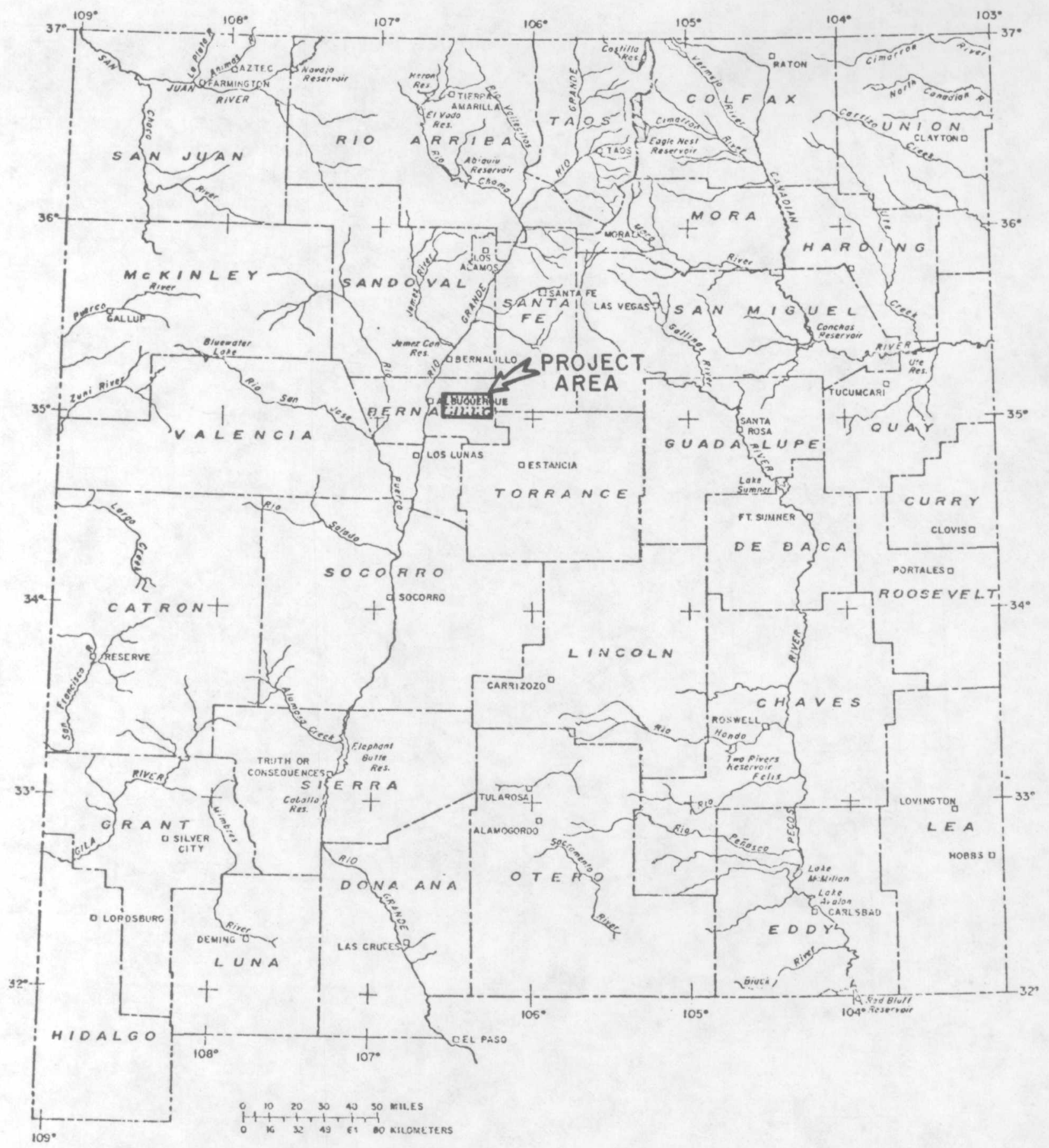

Figure 15.--Location of Tijeras Canyon study area, New Mexico. 
PROJECT TITLE:

COOPERATING AGENCY:
A comprehensive study of the water resources of the lower Rio Grande Valley area, New Mexico

PROJECT CHIEF :

Clyde A. Wilson

PERIOD OF PROJECT: July 1972 to June 1979

Problem.--On May 4, 1971, the governors of New Mexico and Texas supported a proposed areal-resource study, "Rio Grande Regiona1 Environmental Study, Elephant Butte Reservoir, New Mexico, to Fort Quitman, Texas," to evaluate water resource development and management plans using multipurpose approaches to water resource problems. The comprehensive study of water resources of the lower Rio Grande Valley, New Mexico, (fig. 16) will be part of the regional environmental study.

Objectives.--To collect, analyze, and interpret water-resource data in the Rio Grande Valley and adjacent area, from Elephant Butte Reservoir southward to E1 Paso, Texas. Obtain data that will aid the city of Las Cruces to plan for the orderly development of municipal water supplies. Evaluate the availability, quantity, quality, and uses of ground and surface water.

PROJECT TITLE: Reconnaissance of water resources available to urban areas, New Mexico

COOPERATING AGENCY: New Mexico State Engineer

PROJECT CHIEF: William E. Hale

PERIOD OF PROJECT: September 1972 to June 1979

Problem.--Only a few urban areas in New Mexico have been evaluated as to the quantity and quality of ground and surface water available for their use. It is known that in certain areas environmental influences have caused deterioration of the chemical quality of water supplies. In some areas better quality water or larger volumes of water may be available from alternate sources.

Objectives.--To hydrologically evaluate certain urban areas and determine if a suitable supply of water for domestic and industrial uses, projected against anticipated future population growth, will be available when needed. Attempt to define influences that may affect the future quality and quantity of the available water. 


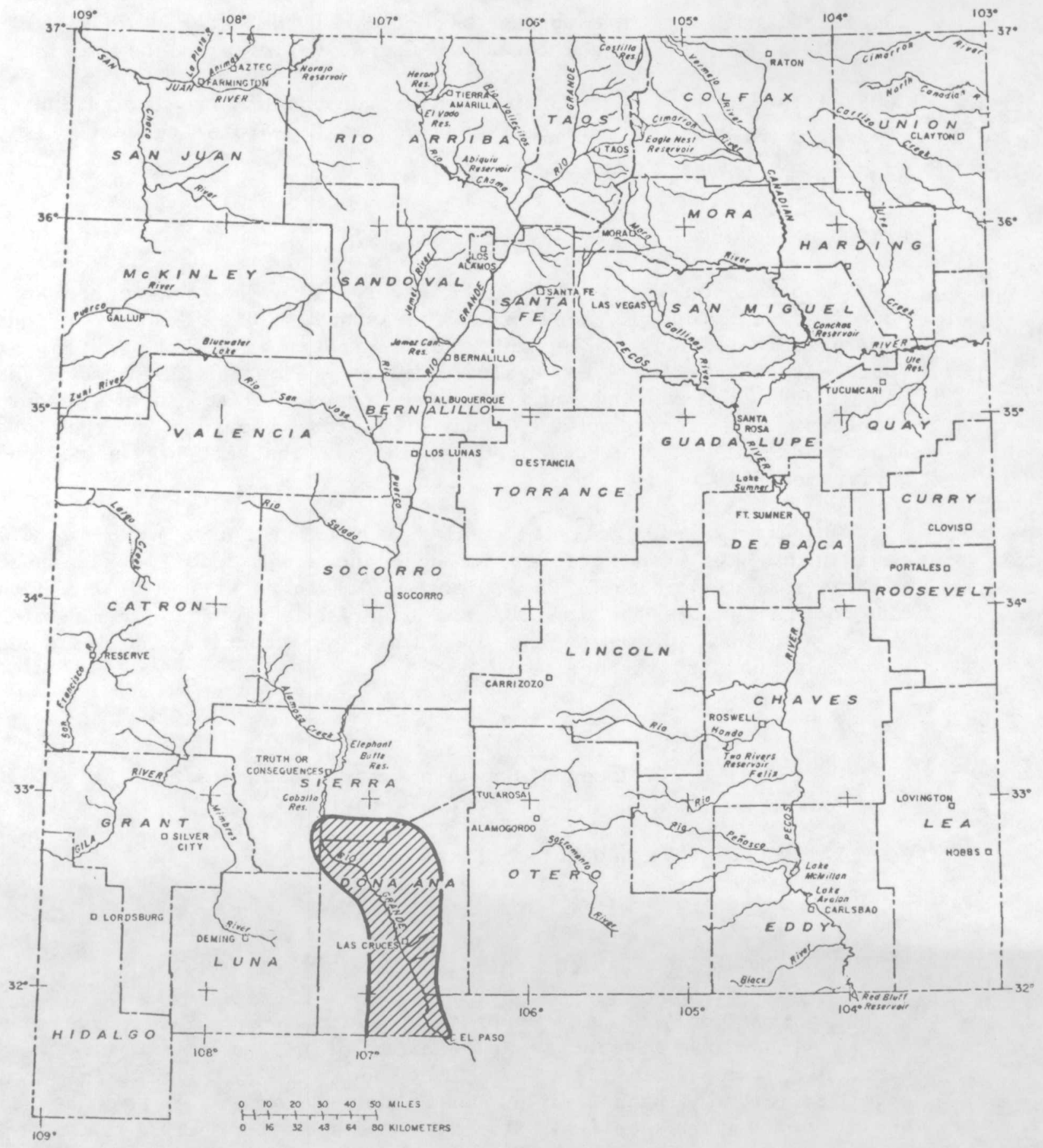

Figure 16.--Location of lower Rio Grande study area, New Mexico. 
PROJECT TITLE:

Effects of energy resources development on the hydrogeologic environment of northwestern New Mexico

COOPERATING AGENCIES: New Mexico State Engineer and New Mexico Bureau of Mines and Mineral Resources

PROJECT CHIEF: $\quad$ Forest P. Lyford

PERIOD OF PROJECT: August 1974 to June 1980

Problem.--Large reserves of minerals are currently being developed in the San Juan Basin of New Mexico (fig. 17). Expanded exploration and production of these minerals will be accompanied with an increasing need for large supplies of water. Production and disposal of waste water in a rather fragile environment is also anticipated. The Bureau of Indian Affairs and numerous communities are concerned with the effects of development of large supplies of ground water in the area. The few available well records in the area indicate that usable ground-water supplies are available locally, however, these probably are somewhat limited.

Objectives.--To evaluate the aquifers within the project area and determine those areas most suitable for ground-water development and waste disposal. Determine ground-water levels for the various aquifers and the effects of various withdrawal plans on water levels. Determine the chemical and radiochemical quality of the ground and surface water. Evaluate sediment loads in both perennial and ephemeral streams. Investigate waste-disposal practices of the mining and petroleum industries to determine if they are contributing to, or are likely to contribute to, the chemical and sediment degradation of ground- or surface-water supplies. If contamination is imminent, various locations or strata will be evaluated for use in disposal of contaminants.

PROJECT TITLE: Mean-annual runoff from streams in New Mexico as related to channel geometry

COOPERATING AGENCY: New Mexico State Engineer

PROJECT CHIEF: John P. Borland

PERIOD OF PROJECT: March 1976 to June 1978

(Completed except for report)

Problem.--New Mexico needs a reliable reconnaissance-type method of determining mean-annual flow at ungaged sites on ephemeral and perennial streams. Mean-annual flow data are useful for planning and in some cases structure design.

Objectives.--To define the relation between channel characteristics and mean-annual flow for streams in New Mexico. 


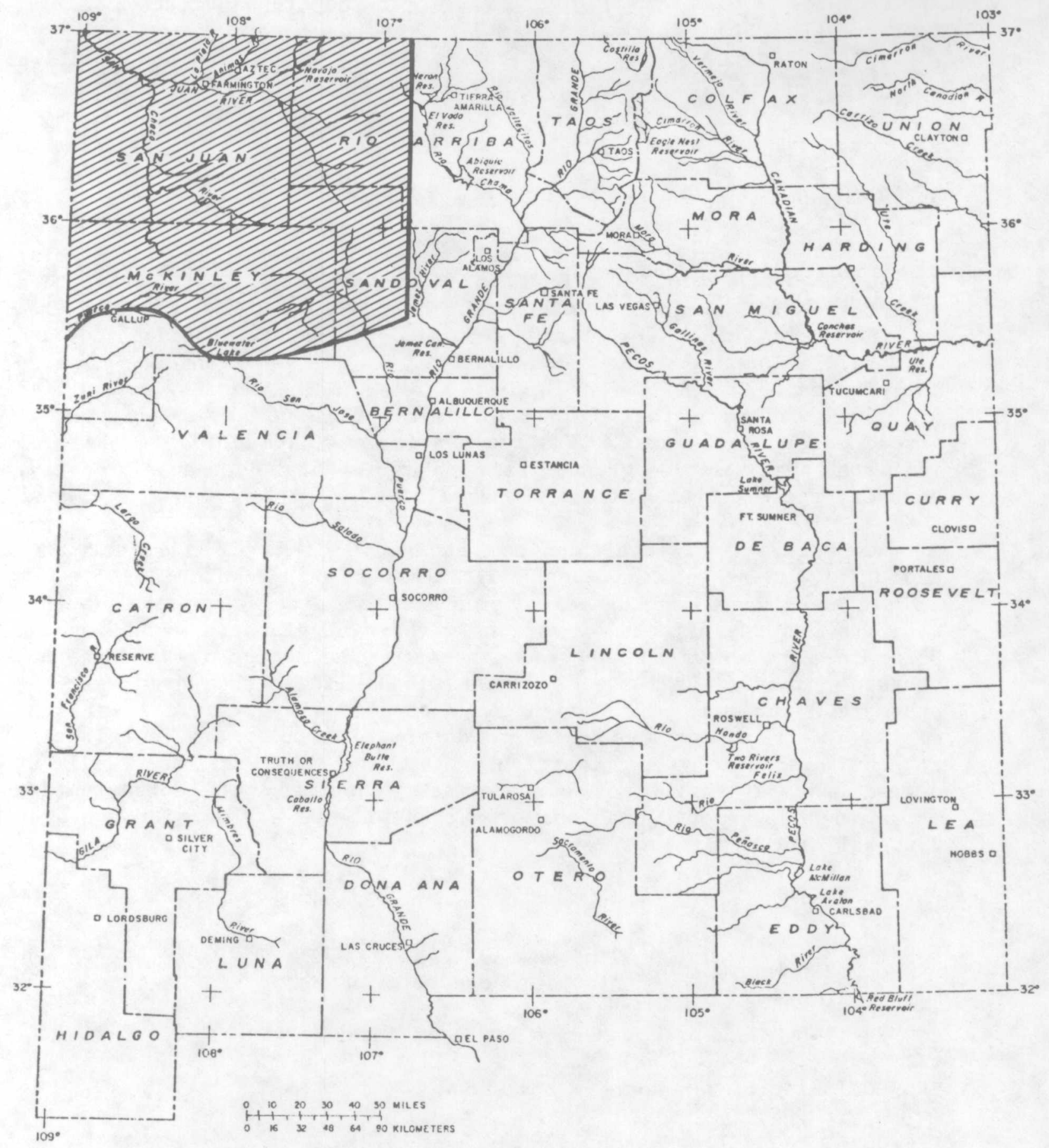

Figure 17.---Location of San Juan Basin study area, New Mexico. 
Hydrologic assessment of the Elephant Butte

Irrigation District and evaluation of

additional drilling sites in the Mesilla Valley, Dona Ana County, New Mexico

COOPERATING AGENCY: Elephant Butte Irrigation District

PROJECT CHIEF: Clyde A. Wilson

PERIOD OF PROJECT: February 1976 to June 1979

Problem.--In August 1975 the drilling and construction of five large-capacity irrigation wells was completed for the Elephant Butte Irrigation District (fig. 18). The Elephant Butte Irrigation District plans to drill more irrigation wells of similar depth and design if these five wells can continue to provide good quality water. The present hydrologic and hydraulic characteristics of the proposed well areas have not been investigated.

Objectives.--To determine coefficients of transmissivity and storage. To monitor water quality during the two- to three-year period following the initial use of the District well area and in the vicinity of irrigation wells at the Berino pumping station. To evaluate the present well field relative to water quality, availability and potential problems in maintaining an acceptable long term water supply.

PROJECT TITLE:

COOPERATING AGENCIES:

PROJECT CHIEF :

PERIOD OF PROJECT:
Urban flood-hydrology of Albuquerque area, New Mexico

Problem.--The city of Albuquerque and the Albuquerque Metropolitan Arroyo Flood Control Authority (fig. 19) require reliable flood-frequency data for design of urban drainage works and regulation of urban development. Present methodology uses unverified empirical relations and data from other urban areas. There is little data presently available regarding the chemical quality of storm runoff in the Albuquerque area.

Objectives.--To define runoff hydrograph characteristics from urban basins in the Albuquerque area; relate the hydrograph characteristics to measurable basin and climatic variables. To investigate the applicability of empirical relations developed for other urban areas to the Albuquerque area; specifically, relations used to compute time and peak coefficients used in the Colorado urban hydrograph procedure. To develop relations between magnitude of flood discharges and measurable basin and climatic variables for watersheds in the Albuquerque area; and to provide estimates of the chemical-quality of runoff. 


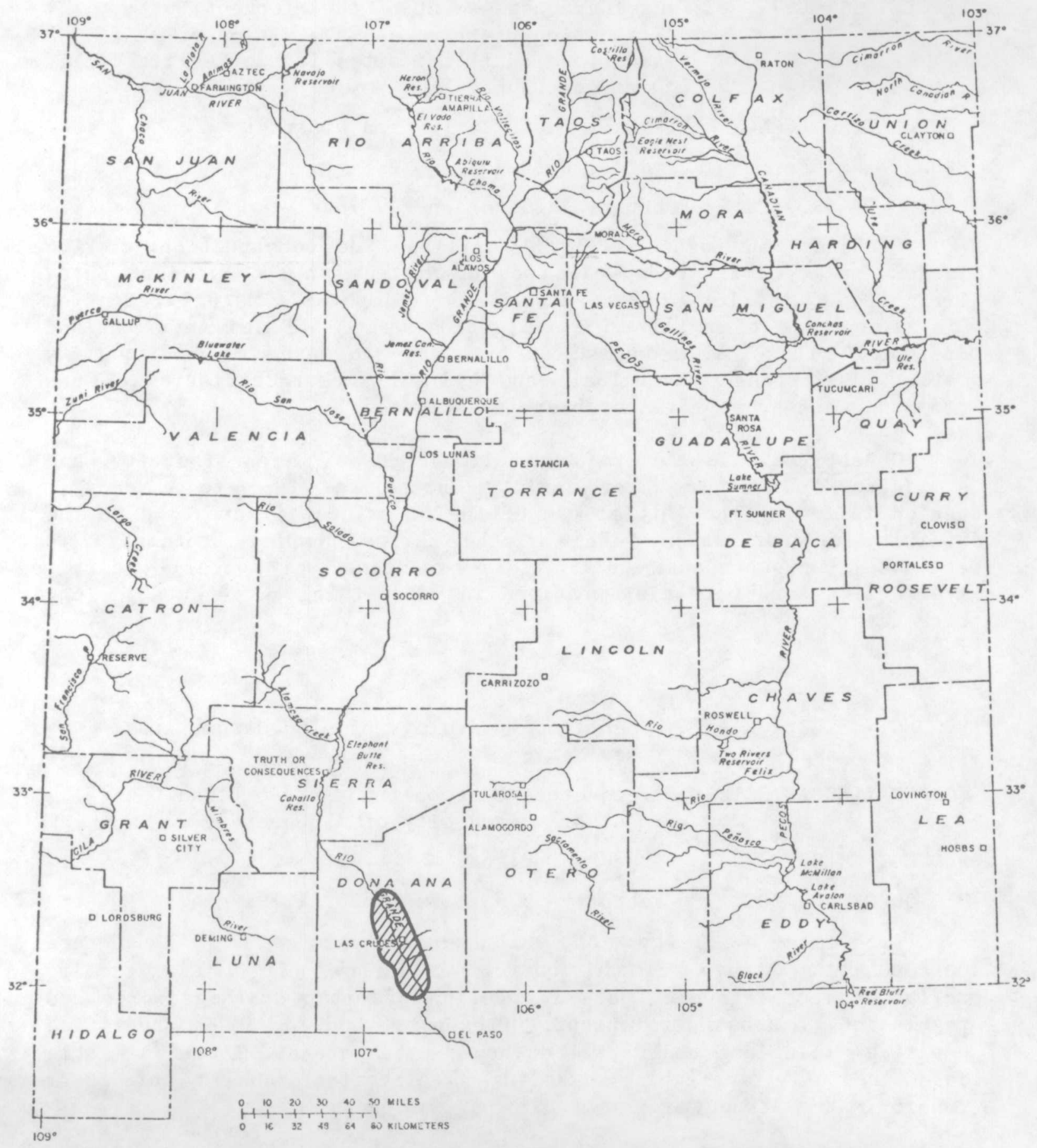

Figure 18.--Location of the Elephant Butte Irrigation District evaluation study area, New Mexico. 


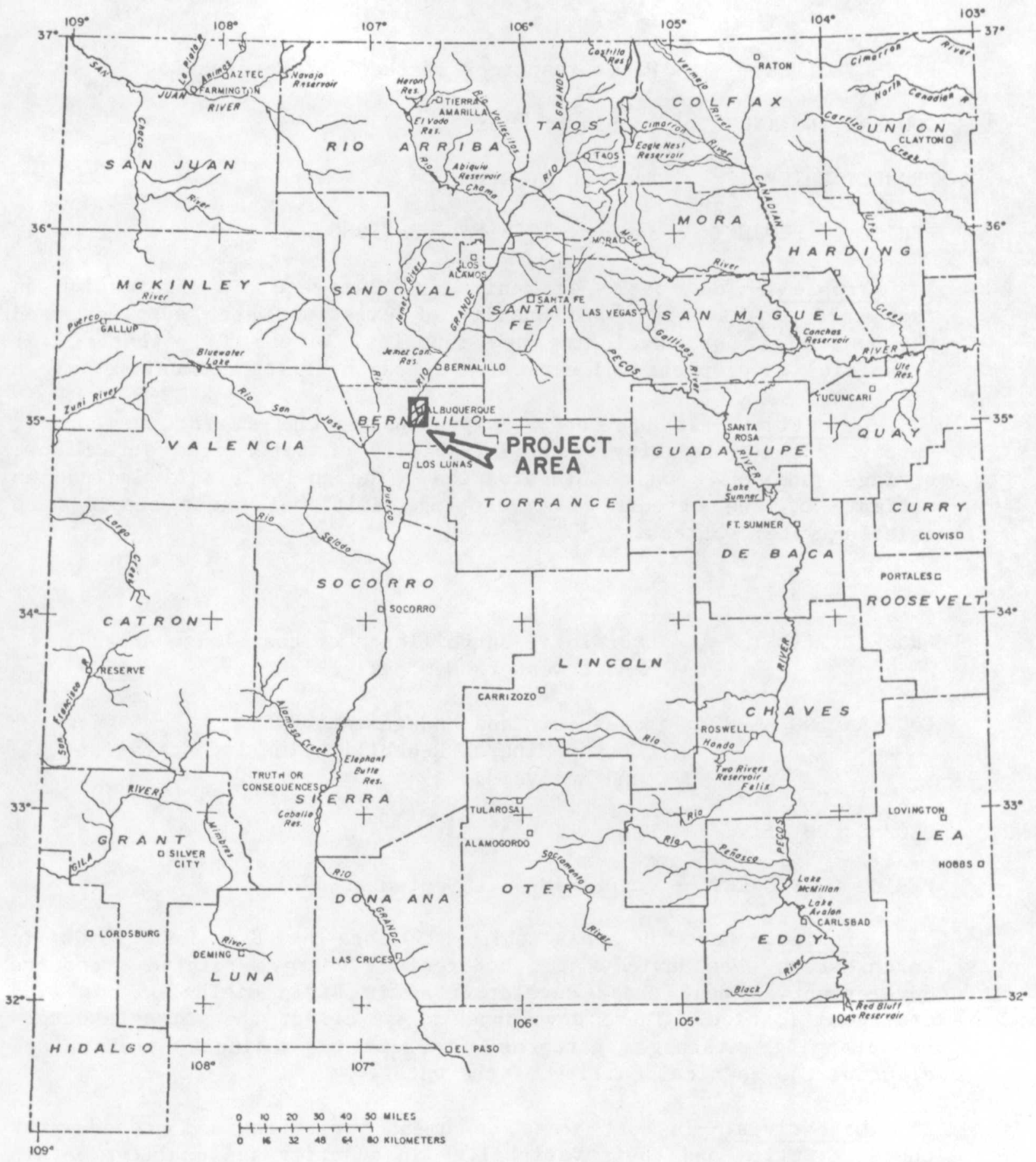

Figure 19.--Location of the Albuquerque, New Mexico flood-hydrology study area. 
PROJECT TITLE :

Water resources of the Zuni Reservation

COOPERATING AGENCY: Pueblo of Zuni

PROJECT CHIEF : Brennon R. Orr

PERIOD OF PROJECT: January 1978 to June 1980

Problem.--The Pueblo of Zuni (fig. 20) requires information on the yield, variability, and quality of existing water supplies, and the potential for developing new supplies. There is potential for industrial development and expansion of the existing communities.

Objectives.--To provide a comprehensive analysis of the source, supply, chemical quality, and availability of water from streamflow, springs, and wells on the reservation. The analysis will include an estimate of the effects of developing additional water supplies on existing water sources.

PROJECT TITLE :

Hydrologic surveillance of coal-lease areas in northwestern New Mexico

COOPERATING AGENCY: Bureau of Land Management--EMRIA

(Energy Mineral Rehabilitation Investigation and Analysis)

PROJECT CHIEF: Henry R. Hejl, Jr.

PERIOD OF PROJECT: August 1974 to September 1981

Problem.--Certain areas (fig. 21) of the San Juan Basin in northwestern New Mexico are undergoing energy related resource development. Among these developments are strip mining of coal and coal gasification. These developments may effect the water resources by changing drainage patterns, increasing sediment yield, and altering the chemical quality of the water.

Objectives.--In coal areas, document streamflow and ground-water characteristics and their variability in quantity and quality; obtain knowledge of the hydrologic system and of the principles, processes, and effects of coal extraction and associated development on the quantities and quality of water resources in the coal-lease areas.

Reports published or released during fiscal year 1976.--U.S. Department of Interior, 1977, Resource and potential reclamation evaluation, Bisti west study site, Bisti coal field; U.S. Bureau of Land Management EMRIA Report No. 5-1976, p. 69-80. 


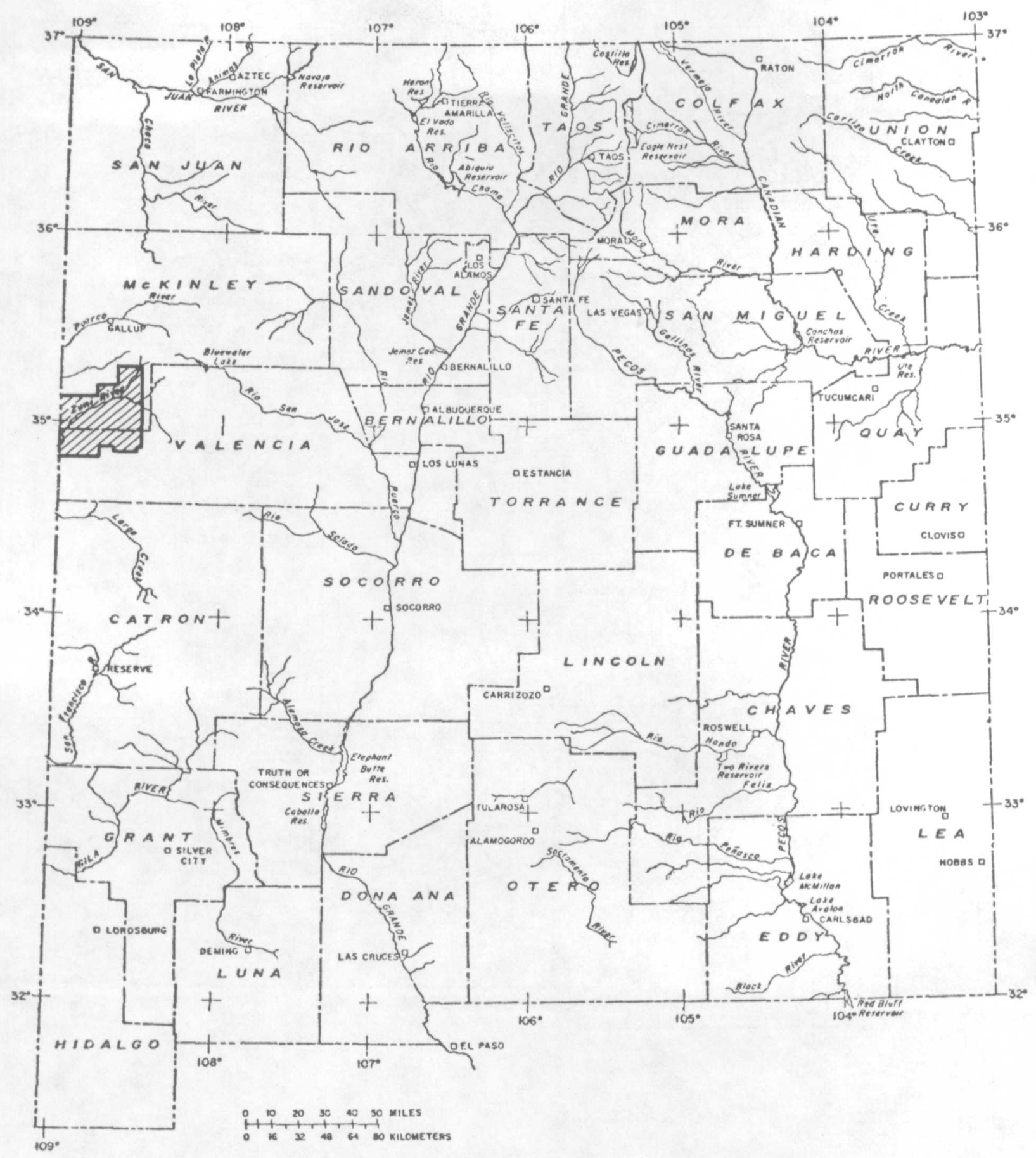

Figure 20.--Location of the Zuni Indian Reservation study area in New Mexico. 


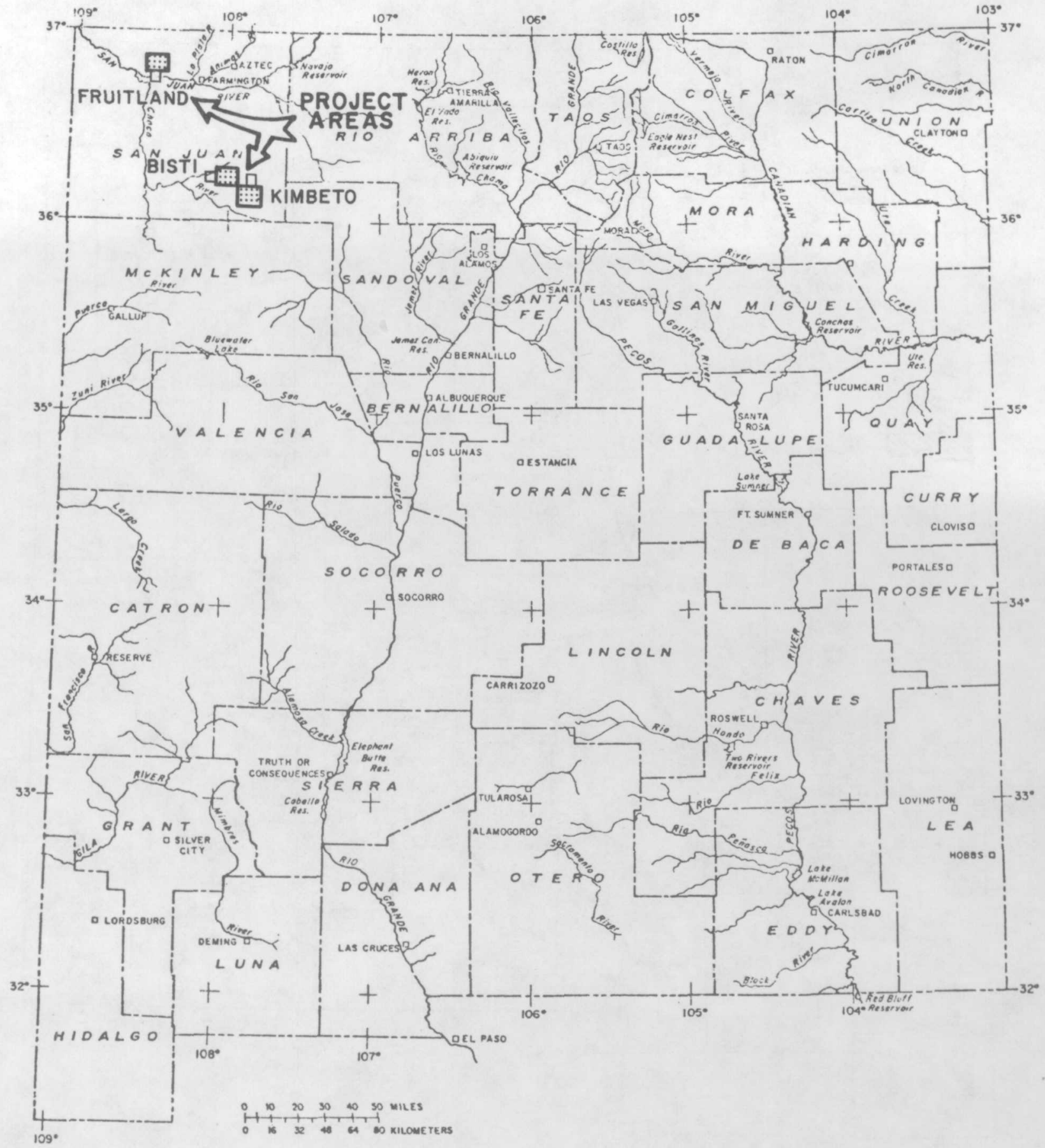

Figure 21.--Location of hydrologic surveillance of coal-lease area sites in northwestern New Mexico. 
COOPERATING AGENCY: Bureau of Indian Affairs - Albuquerque

PROJECT CHIEF: Forest P. Lyford

PERIOD OF PROJECT: October 1974 to September 1980

Problem.--The Bureau of Indian Affairs, Albuquerque area office, is involved with the welfare of Indian inhabitants of several reservations and pueblos. A major responsibility is the development and maintenance of water supplies for domestic and stock use. They are also interested in the development of water supplies for mineral exploration and the quantity and quality of surface-water flows. The Albuquerque area office of Bureau of Indian Affairs makes requests to the Geological Survey for assistance in these areas.

objectives.--To conduct hydrologic and geologic investigations concerned with the development and maintenance of domestic and stock water supplies on Indian lands as requested by the Bureau of Indian Affairs; to evaluate the need for geologic and hydrologic investigations concerned with the development of other resources. The initial investigation will be on the Mescalero-Apache Indian reservation in south-central New Mexico. Four proposed water-we11 sites will be evaluated for their water-supply potential. 
PROJECT TITLE:

Hydrologic investigations related to a radioactive waste repository in salt, southeastern New Mexico

COOPERATING AGENCY: Department of Energy

PROJECT CHIEF: Jerry W. Mercer

PERIOD OF PROJECT: May 1975 to September 1979

Problem.--Sandia Laboratories is evaluating a potential repository for medium- to high-level radioactive wastes in salt beds in southeastern New Mexico (fig. 22). Information is needed on the occurrence and movement of water in the various water-bearing beds above and below the salt to assist in evaluation of the long-term hydrologic integrity of the site as well as assess the environmental impact of the proposed project. Information is needed on the potential increased interchange of ground water in the Rustler Formation as a result of subsidence of this formation caused by the mining of potash.

Objectives.--To define the general occurrence of ground water in the area from about Roswell southeastward to the State line. To define in detail the direction and rate of movement of ground water in the Rustler Formation in the vicinity of the site, and less detailed definition downgradient to about 30 miles from the site; also to define potential for increased interchange of water locally in the Rustler Formation as a result of subsidence of this formation caused by mining of potash in nearby areas.

Reports published or released during fiscal year 1977.--

Mercer, J. W., and Orr, B. R., 1977, Review and analysis of hydrogeologic conditions near the site of a potential nuclear waste repository, Eddy and Lea Counties, New Mexico: U.S. Geological Survey Open-File Report 77-123, 35 p., 7 figs . 


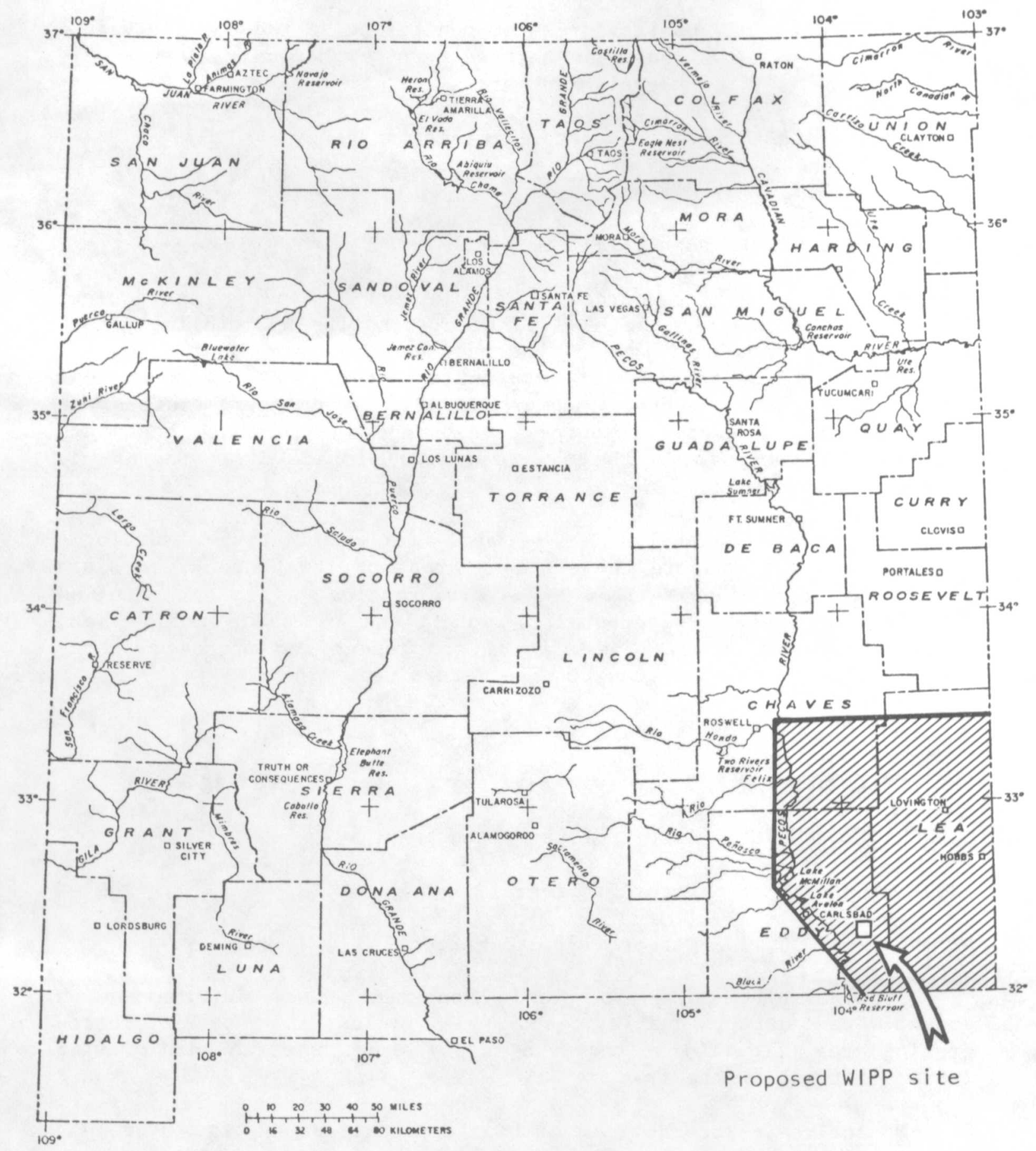

Figure 22.--Location of radioactive waste repository study area and proposed Waste Isolation Pilot Plant Site near Carlsbad, New Mexico. 
PROJECT TITLE:

Quality-of-water monitoring in the Chaco River basin in northwestern New Mexico's energy development area

COOPERATING AGENCY: Environmental Protection Agency

PROJECT CHIEF: Kim Ong

PERIOD OF PROJECT: April 1976 to April 1980

Problem.--Energy-resources development and environment protection has created the need to understand the hydrologic system. The Chaco River basin (fig. 23) has not been extensively studied, and therefore, data on the quantity and quality of the water resources in the basin are very sparse. The hydrologic impact, particularly on water quality of energy resource development in the Chaco basin and ultimately downstream in the San Juan and Colorado River Basins, is not fully understood.

Objectives.--Establish a network for collecting hydrologic information in the energy development areas of the Chaco River basin in northwestern New Mexico. The information will help define baseline or present water-quality conditions of both surface- and ground-water resources. The effects of present and proposed energy developments in the area can then be determined.

PROJECT TITLE: Ground water in the Rio Puerco grazing area

COOPERATING AGENCY: Bureau of Land Management

PROJECT CHIEF: $\quad$ Peter F. Frenze1

PERIOD OF PROJECT: October 1977 to March 1978

Problem.--The Bureau of Land Management needs information on ground-water depth, quality, and well yields in the Rio Puerco grazing area (fig. 24) so they can supply stock water to each grazing lease allotment in the area.

Objectives.--Present data and interpretations of the hydrology of the area and assist Bureau of Land Management planners in selecting well sites and pipeline routes to deliver stock water to each allotment in the area. 


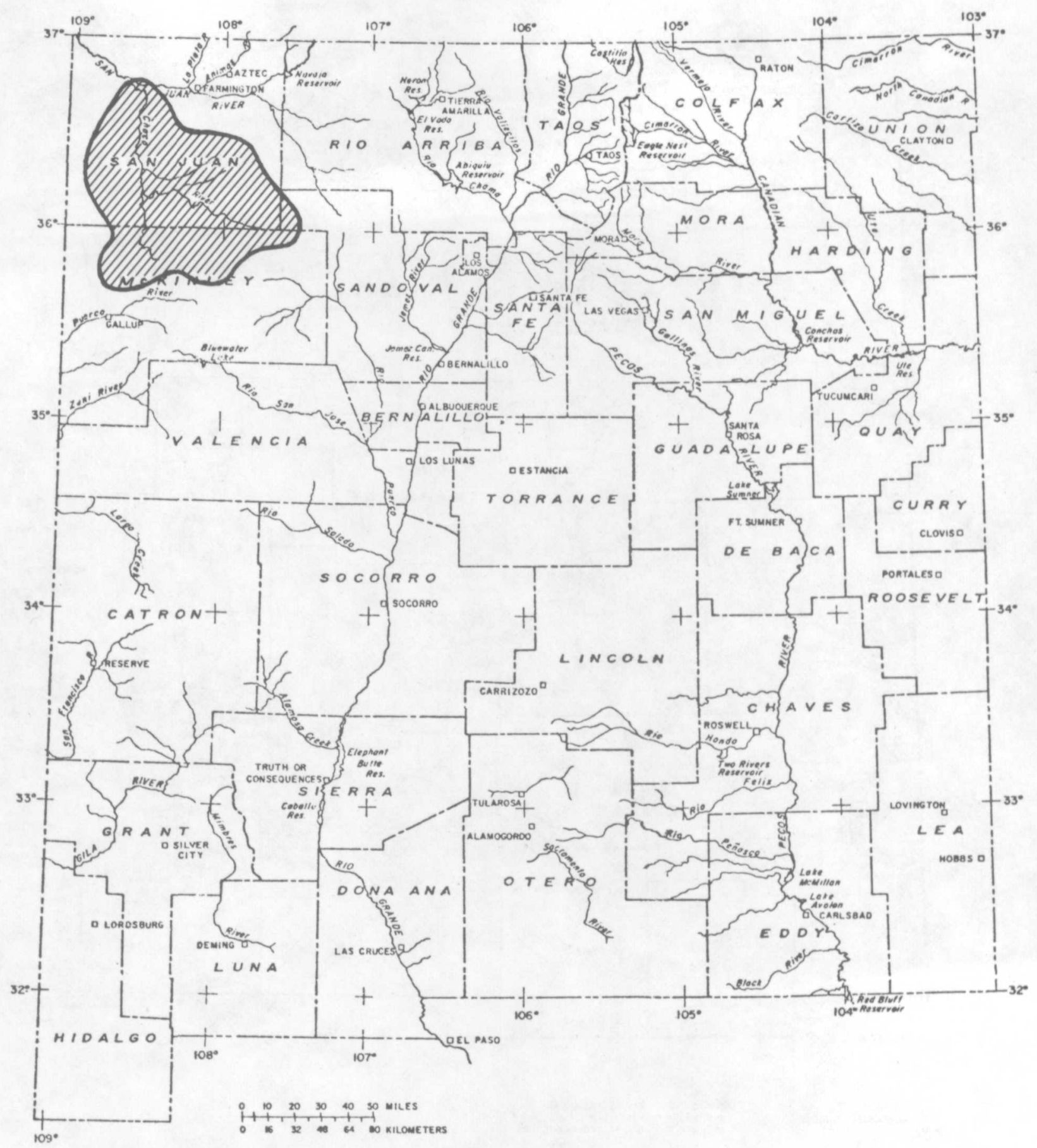

Figure 23.--Location of Chaco River basin study area in northwestern New Mexico. 


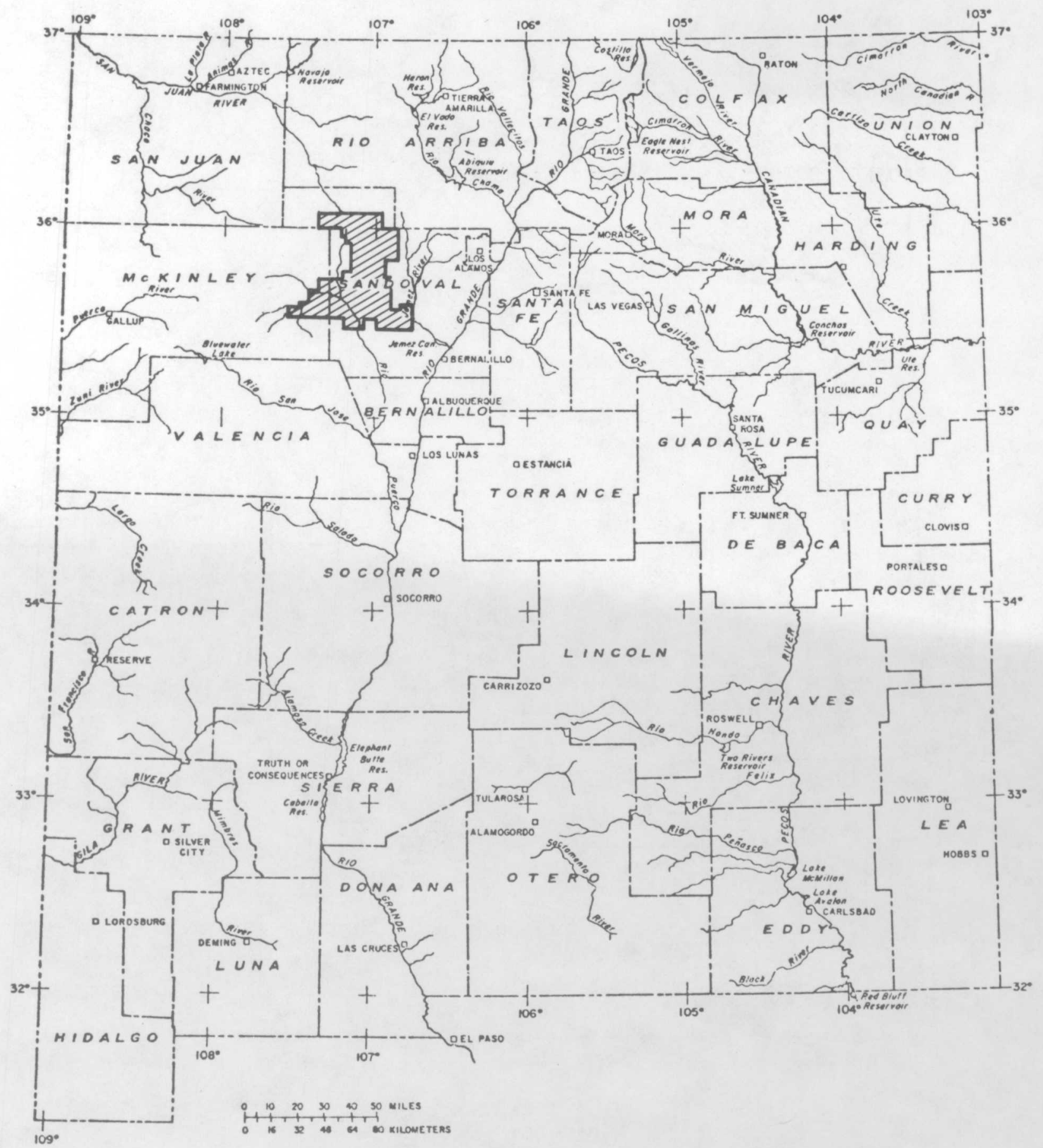

Figure 24.--Location of the Rio Puerco grazing area study in New Mexico. 
PROJECT TITLE:

A study of aquifers in the Capulin area as a possible supplemental water supply for Raton, New Mexico

COOPERATING AGENCY: Bureau of Reclamation

PROJECT CHIEF: Donald L. Hart

PERIOD OF PROJECT: April 1977 to August 1978

Problem.--The city of Raton, New Mexico, depends on a limited supply of surface water for municipal and industrial supply. Planned housing developments are limited by lack of a dependable water supp1y. The current drought may produce water shortages. It has been proposed that ground-water supplies be developed for use in conjunction with existing surface-water supplies for the city of Raton to meet future demands.

Objectives.--Attempt to define the extent, thickness, yield, and economic yield of ground-water aquifers in the area between Raton and Capulin, New Mexico (fig. 25); and to study water-quality and the effects of pumping on existing supplies in the area.

PROJECT TITLE: Hydrologic investigations of the Laguna Pueblo, New Mexico

COOPERATING AGENCY: Bureau of Indian Affairs

PROJECT CHIEF: $\quad$ Forest P. Lyford

PERIOD OF PROJECT: October 1977 to September 1980

Problem.--The Laguna Indians are in need of more and better quality water for irrigation and public supply (fig. 26).

Objectives.--Determine the quantity and quality of water available for irrigation and public supply, and the possible effects of present and future water-resources development on the hydrologic system. 


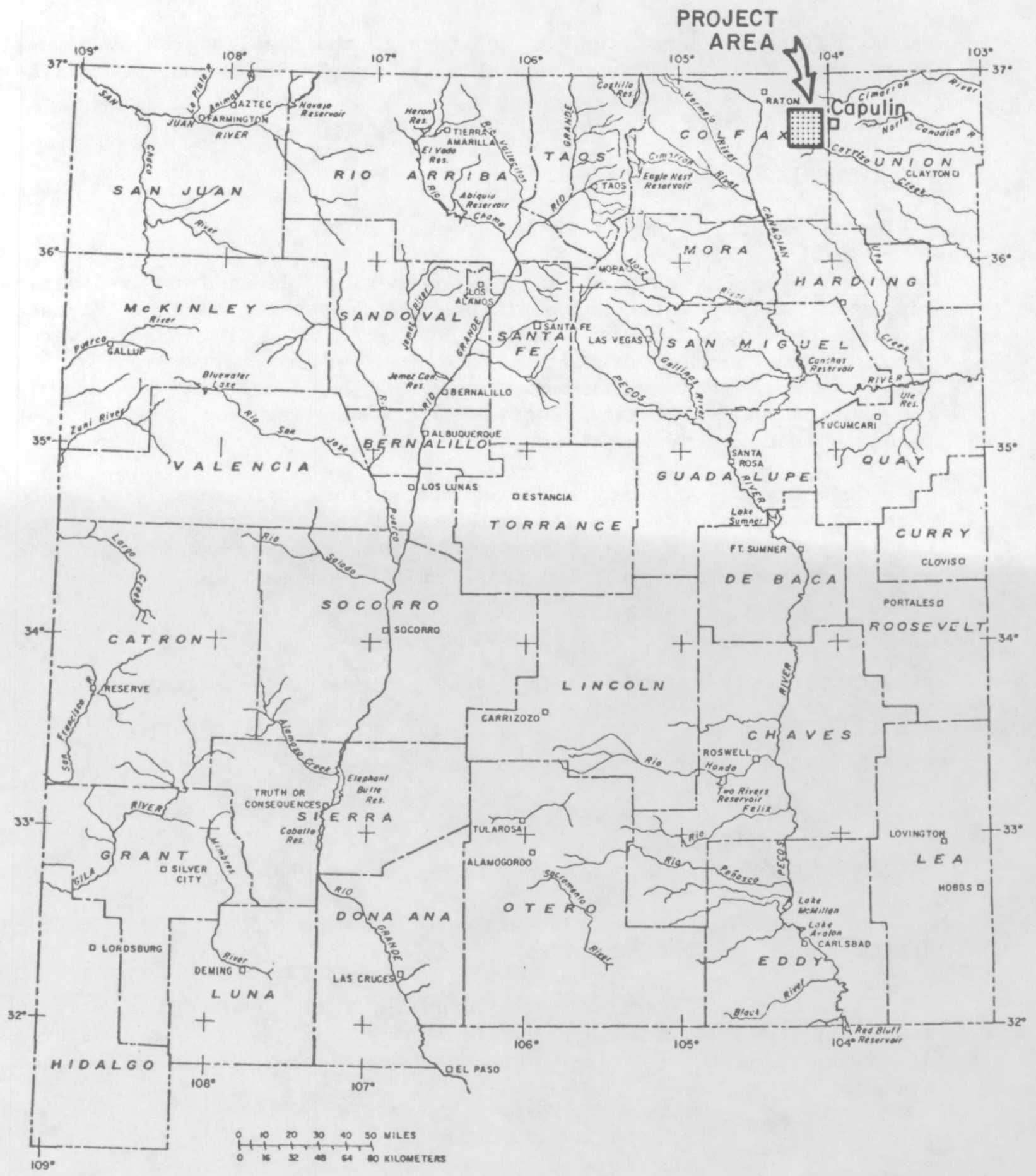

Figure 25.--Location of the Capulin ground-water study area in New Mexico. 


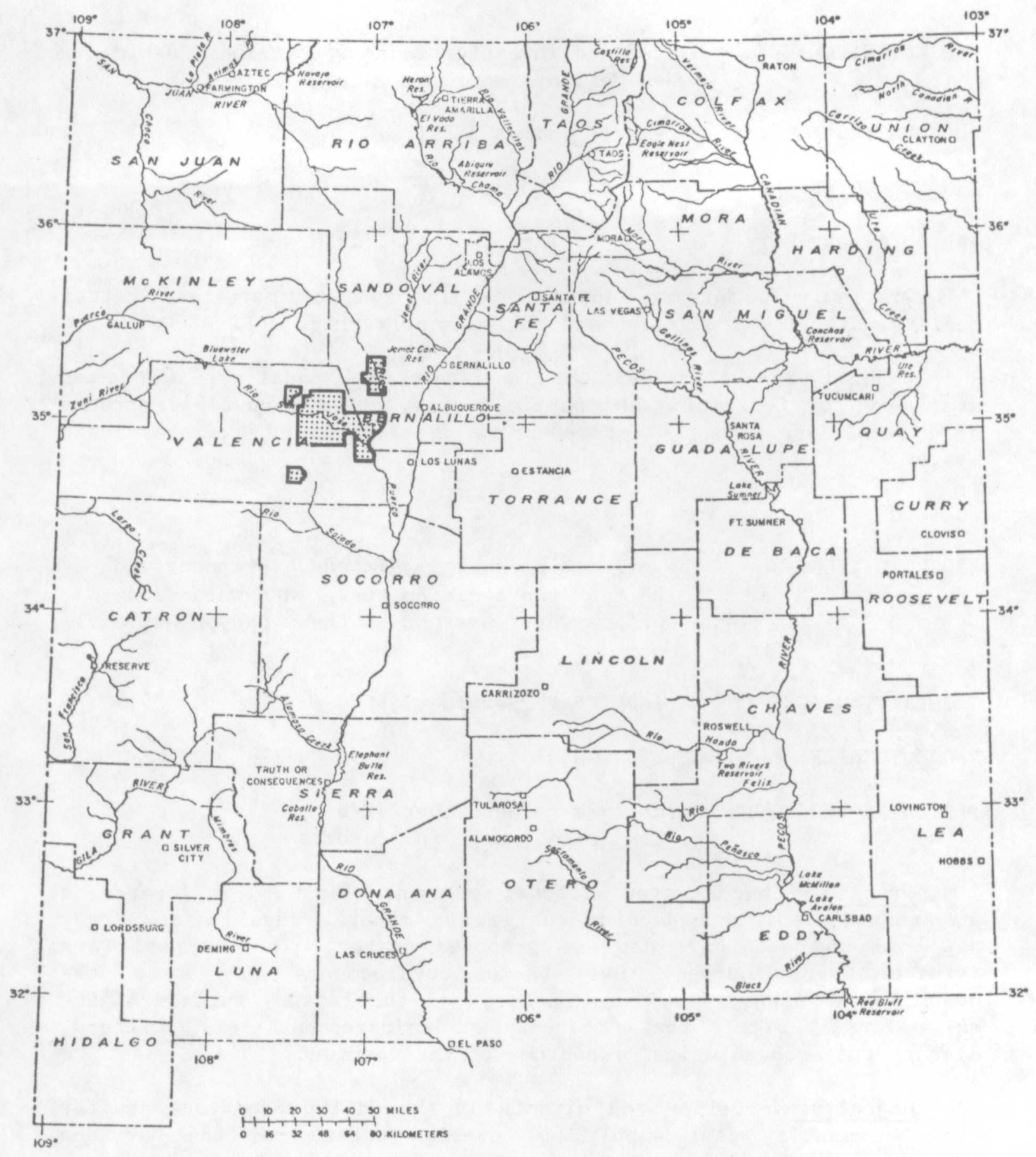

Figure 26.--Location of Laguna Pueblo lands study area, New Mexico. 
PROJECT TITLE:

Hydrologic investigations of the Acoma Pueblo, New Mexico

COOPERATING AGENCY: Bureau of Indian Affairs

PROJECT CHIEF: $\quad$ Forest P. Lyford

PERIOD OF PROJECT: October 1977 to September 1980

Problem.--The Acoma Indians are in need of more and better quality water for irrigation and public supply (fig. 27).

Objectives.--Determine the quantity and quality of water available for irrigation and public supply, and the possible effects of present and future water-resources development on the hydrologic system.

PROJECT TITLE :

The effects of energy-related developments in the San Juan Basin on the ground-water and surface-water systems at Chaco Canyon National Monument

COOPERATING AGENCY: National Park Service

PROJECT CHIEF: Henry R. Hejl

PERIOD OF PROJECT: March 1978 to September 1978

(Completed except for report)

Problem.--Chaco Canyon National Monument (fig. 28) is located in an area of rapidly expanding energy and mineral development. Many new coal and uranium mines are proposed nearby. The National Park Service is concerned that these developments may harm the ground-water supply for the monument, and that nearby surface mining may adversely affect the surface-water drainages and this, in turn, disturb the archaeological resources of the monument.

Objectives.--Define the effects in the Gallup Sandstone aquifer (the Monument's water supply) of pumping water from the Morrison Formation. Natural leakage between the aquifers is thought to be small and predictable, but the effect of the many thousands of uranium test holes on the degree of interconnection between aquifers is unknown. The effects of surface mining on the discharge and sediment content of the Chaco River and Gallo Wash are unknown. Implement a monitoring program to establish baseline conditions for discharge, sediment transport, and alluvial channel characteristics. Attempt to predict the effects of various mining and reclamation practices on the alluvial channels in the monument. 


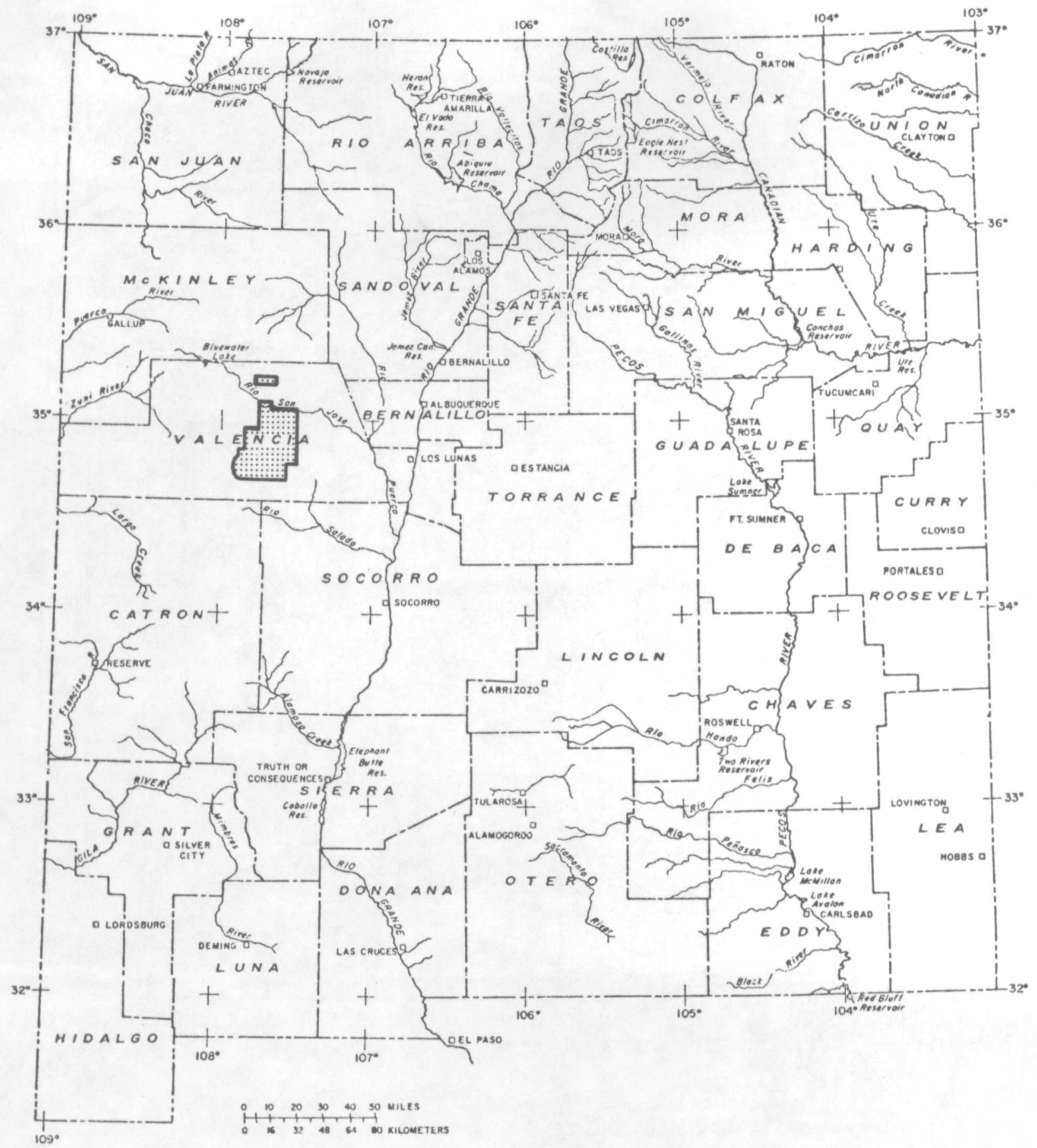

Figure 27.--Location of Acoma Pueblo lands study area, New Mexico. 


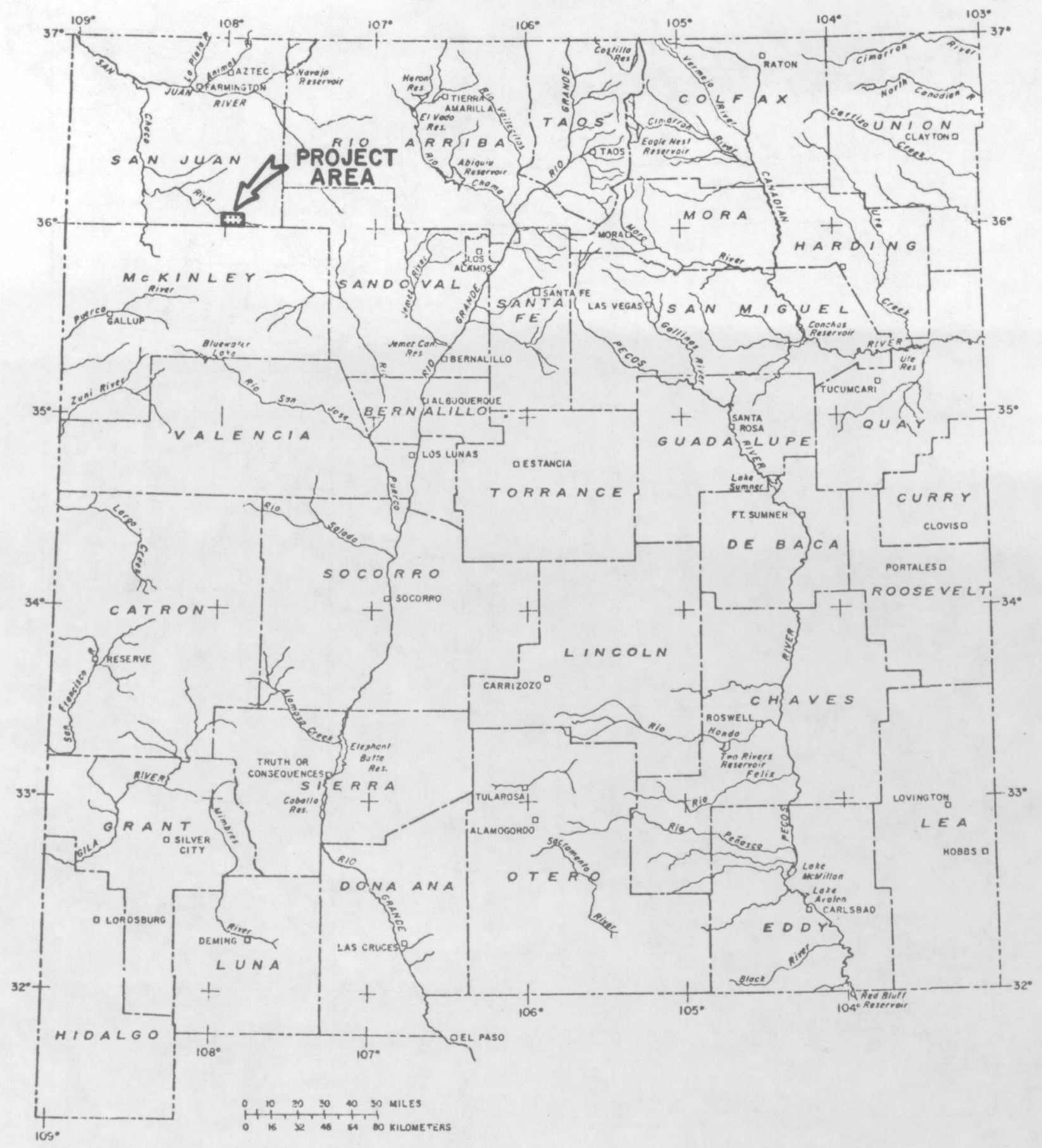

Figure 28.--Location of Chaco Canyon National Monument study area, New Mexico. 
Water resources monitoring of coal development

in the San Juan Basin, New Mexico

COOPERATING AGENCY: None

PROJECT CHIEF: Jack D. Dewey

PERIOD OF PROJECT: Continuous since January 1977

Problem.--Coal mining and associated activities in the San Juan Basin (fig. 29) may have an adverse effect on the water resources of the area. Mine dewatering, changes in land use, waste disposal, stream-channel realignment, and water withdrawals for industries and municipalities may alter surface- and ground-water systems, interfere with traditional water uses, and may cause deterioration of remaining water resources.

Objectives.--Detect and document changes in water quality or quantity that may result from coal mining and associated activities. 


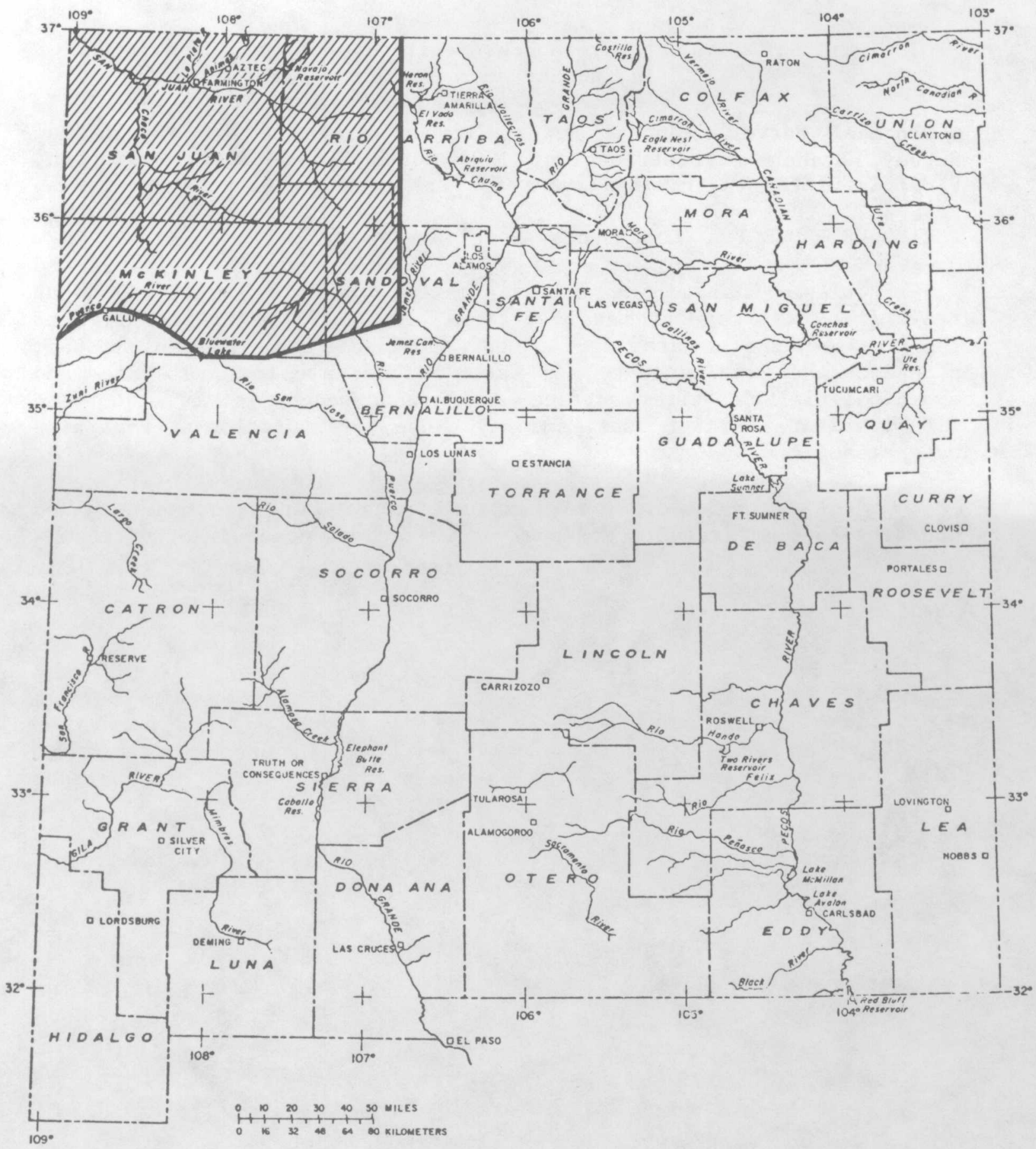

Figure 29.--Location of study area for coal development expanded monitoring program in New Mexico. 
Professional papers, water-supply papers, bulletins, and the Geological Survey's Annual Report are sold by the U.S. Geological Survey, Branch of Distribution, 1200 South Eads Street, Arlington, Virginia 22202 (authorized agent of the Superintendent of Documents, Government Printing Office). Circulars are free upon request to the U.S. Geological Survey, National Center, Reston, Virginia 22092. Water-resources investigations folders for each of the 50 states and Puerto Rico also are free upon request. Hydrologic Investigations Atlases, Hydrologic Unit Maps, and other maps pertaining to New Mexico are sold by the U.S. Geological Survey, Branch of Distribution (P.0. Box 25286, Denver Federal Center, Lakewood, Colorado 80225).

Records of streamflow, ground-water levels, and quality of water have been published for many years as Geological Survey Water-Supply Papers (WSP) in the series explained below. Beginning with the 1975 water year, however, these series have been replaced by a new publication series, "U.S. Geological Survey Water-Data Reports." This new series combines under one cover for each state streamflow data, water-quality data for surface and ground water, and ground-

water level data from the basic network of observation wells. For New Mexico, it is entitled "Water Resources Data for New Mexico Water Year 1975: U.S. Geological Survey Water-Data Report NM-75-1." Other publication series of general interest also are explained below. Further information on these publications can be obtained from the District Chief, Water Resources Division, Albuquerque, New Mexico.

Streamflow records.--Records of daily flows of streams prior to 1971 were published in the Water-Supply Paper series "Surface Water Supply of the United States" which was released in numbered parts as determined by natural drainage basins. Until 1961 this was an annual series; monthly and yearly summaries of these data were compiled in two reports: "Compilation of Records of Surface Waters of the United States through September 1950" and "Compilation of Records of Surface Waters of the United States October 1950 to September 1960." For the period 1960-70, two 5-year compilations were published. Data for New Mexico are published in Part 7 volume 2, Part 8 volumes 1 and 2, and Part 9 volumes 2 and 3. For the years 1961-74, these data also were released annually on a State-boundary basis.

Ground-water records.--Ground-water levels and artesian pressures in observation wells prior to 1975 were reported by geographic areas in a 5-year water-supply paper series. Data for New Mexico are in "Ground-Water Levels in the United States, Southwestern States." 
Quality-of-water records.--Data on quality of surface water prior to 1971 were published annually in the water-supply paper series "Quality of Surface Waters of the United States," which also was release of surface water prior to 1971 were published annually in the water-supply paper series "Quality of Surface Waters of the United States," which also was released in numbered parts as determined by natural drainage basins. Data for New Mexico is in Parts 7, 8, and 9. For the years 1964-74, these data also were released annually on a state-boundary basis.

Methods of estimating the frequency and magnitude of floods for selected streams are given in the water-supply paper series "Magnitude and Frequency of Floods in the United States," which is composed of reports released in parts by drainage basins; data for New Mexico are in Parts 7, 8, and 9. At present, the Geological Survey also is outlining flood-prone areas on topographic maps as part of a nationwide federal program for managing flood losses. In New Mexico, 67 topographic maps have been completed. Flood-prone area maps of New Mexico are 1isted in "Index of flood maps prepared by the U.S. Geological Survey through 1973," Water Resources Investigations 57-73. Information on these maps is available from the District Chief, Water Resources Division, Albuquerque.

Summaries of research in progress and results of completed investigations are published each fiscal year in the Professional Papers "Geological Survey Research." Recent editions are: fiscal year 1974, PP 900; 1975, PP 975; 1976, PP 1000.

A more complete State List of reports of the U.S. Geological Survey is given in a pamphlet "Geologic and Water-Supply Reports and Maps-- New Mexico." Summary statements about the immediate national water situation are presented in the Water Resources Review, which is issued monthly. The State List and the Review may be obtained free on application to the U.S. Geological Survey, 420 National Center, Reston, Virginia 22092.

Indexes to the "Catalog of Information on Water Data" are available free from the District Chief in Albuquerque or the Office of Water Data Coordination, U.S. Geological Survey, 417 National Center, Reston, Virginia 22092. Current editions are as follows: (1) station listings for streamflow and stage, quality of surface water, and quality of ground water, 1974 [21 volumes by water-resources regions--stations in New Mexico are listed in Volumes 11 (Arkansas-White-Red Region), 12 (Texas-Gulf Region), 13 (Rio Grande Region), 14 (Upper Colorado Region), and 15 (Lower Colorado Region)]; (2) index to areal investigations and miscellaneous water-data activities, 1970 [one volume]; and (3) index to ground-water stations, 1968 [one volume].

The "U.S. Geological Survey Annual Report, Fiscal Year 1976" provides a comprehensive description of the Federal Government's largest earth-science agency. 
Reports of investigations--selected references

Selected references on water resources in New Mexico are grouped in this report as follows: (1) U.S. Geological Survey publications that can be purchased or obtained from the Geological Survey and publications that are released either to the open-file or as water-resources investigations reports which can be inspected at specific offices; (2) reports prepared by the Geological Survey in cooperation with specific agencies which can be obtained from the cooperating agencies; and (3) other publications such as technical journals. New reports are announced monthly in "New Publications of the Geological Survey." Subscriptions to the monthly list are available free on request to the U.S. Geological Survey, 329 National Center, Reston, Virginia 22092.

\section{Professional papers}

352-G. Channel and hillslope processes in a semiarid area, New Mexico, by L. B. Leopold, W. W. Emmett, and R. M. Myrick, 1966, p. 193-253.

372-H. General summary of effects of the drought in the Southwest, by H. E. Thomas, 1963, 22 p.

386-D. Disposal of uranium-mill effluent by well injection in the Grants area, Valencia County, New Mexico, by S. W. West, 1972 , $28 \mathrm{p}$.

450-E. Short papers in geology, hydrology, and topography, Articles $180-239,1963,189$ p. Contains the following articles, which are not available separately.

213. Correlation of some glacial deposits in New Mexico, by G. M. Richmond, p. 121-125.

225. Ground water in Cenozoic fill in collapse structures, southeastern Eddy County, New Mexico, by J. B. Cooper, p. 152-153.

229. Flood peaks related to hydrologic factors in the Southwest, by M. A. Benson, p. 161-163.

462-F. Sediment transport in the Rio Grande, New Mexico, by C. F. Nordin, Jr., and J. P. Beverage, 1965, 35 p.

491-A. Introduction, spread, and areal extent of saltcedar (Tamarix) in the western states, by T. W. Robinson, 1965, 12 p. 
492. Thermal springs of the United States and other countries-a summary by G. A. Waring, 1965,383 p.

521-A. Regional hydrogeology of the Navajo and Hopi Indian Reservations, Arizona, New Mexico, and Utah, by M. E. Cooley, J. W. Harshbarger, J. P. Akers, and W. F. Hardt, with a section on vegetation, by 0. N. Hicks, 1969,61 p.

562-J. Summary of alluvial-channel data from Rio Grande conveyance channel, New Mexico, 1965-69, by J. K. Culbertson, C. H. Scott, and J. P. Bennett, 1972, 49 p.

650-B. Development of ground-water supplies on the Pajarito Plateau, Los Alamos County, New Mexico, by W. D. Purtymun and J. B. Cooper, in Geological Survey Research 1969, Chapter B, by U.S. Geological Survey, 1969, p. 149-153.

708. Ground-water hydraulics, by S. W. Lohman, 1972,70 p.

712-A. Geohydrology of Project Gnome site, Eddy County, New Mexico, by J. B. Cooper and V. M. Glanzman, 1971, 24 p.

778. Embudo, New Mexico, birthplace of systematic stream gaging, by A. H. Frazier and W. L. Heckler, 1971, 23 p.

813-C. Summary appraisals of the Nation's ground-water resources-Upper Colorado Region, by Don Price and Ted Arnow, 1974, 40 p.

813-D. Summary appraisals of the Nation's ground-water resources-Rio Grande Region, by S. W. West and W. L. Broadhurst, 1975, 39 p.

813-F. Summary appraisals of the Nation's ground-water resources-Texas-Gulf Region, by E. T. Baker, Jr., and J. R. Wa11, 1976, 29 p.

Water-supply papers

1473. Study and interpretation of the chemical characteristics of natural water, 2d edition, by J. D. Hem, 1970, 363 p.

1576-G. Geology and availability of ground water on the Ute Mountain Indian Reservation, Colorado and New Mexico, by J. H. Irwin, 1966, 109 p.

1576-H. Ground-water resources of the southern part of Jicarilla Apache Indian Reservation and adjacent areas [Rio Arriba and Sandoval Counties], New Mexico, by E. H. Baltz and S. W. West, 1967, $89 \mathrm{p}$. 
1601. Saline-water resources of New Mexico, by J. W. Hood and L. R. Kister, 1962,70 p.

1619-G. Causes of depletion of the Pecos River in New Mexico, by H. E. Thomas, 1963, 14 p.

1669-S. Yearly variations in runoff for the conterminous United States, 1931-60, by M. W. Busby, 1963, 49 p.

1800. The role of ground water in the national water situation, by C. L. McGuinness, 1963, 1121 p.

1809-D. An evaluation of aquifer and well characteristics of municipal well fields in Los Alamos and Guaje Canyons, near Los Alamos, [Los Alamos County] New Mexico, by R. L. Cushman, 1965, 50 p.

1812. Public water supplies of the 100 largest cities in the United States, by C. N. Durfor and Edith Becker, 1964, 364 p.

1819-F. Recharge studies on the High Plains in northern Lea County, New Mexico, by J. S. Havens, 1966, 52 p.

1828. Geology and hydrology between Lake McMillan and Carlsbad Springs, Eddy County, New Mexico, by E. R. Cox, 1967, 48 p.

1831. Hydrology of Cornfield Wash area and effects of land-treatment practices, Sandoval County, New Mexico, 1951-60, by D. E. Burkham, 1966, 87 p.

1990. Annotated bibliography on artificial recharge of ground water, 1955-67, by D. C. Signor, D. J. Growitz, and William Kam, $1970,141 \mathrm{p}$.

2020. Subsurface waste disposal by means of wells--a selective annotated bibliography by D. R. Rima, E. B. Chase, and B. M. Myers, 1971,305 p.

2029-E. An appraisal of potential water salvage in the Lake McMillan delta area, Eddy County, New Mexico, by E. R. Cox and J. S. Havens, 1974,26 p.

\section{$\underline{\text { Circulars }}$}

464. Floods in New Mexico, magnitude and frequency, by

$$
\text { L. A. Wiard, } 1962,13 \mathrm{p} \text {. }
$$

554. Hydrology for urban land planning--a guidebook on the hydrologic effects of urban land use, by L. B. Leopold, 1968, 18 p.

556. Estimated use of water in the United States, 1965, by

$$
\text { C. R. Murray, } 1968,53 \text { p. }
$$


601-A. Water for the cities--the outlook, by W. J. Schneider and A. M. Spieker, 1969,6 p.

601-D. Water as an urban resource and nuisance, by H. E. Thomas and W. J. Schneider, 1970,9 p.

601-E. Sediment problems in urban areas, by H. P. Guy, 1970,8 p.

601-F. Hydrologic implications of solid-waste disposal, by W. J. Schneider, $1970,10 \mathrm{p}$.

601-G. Real-estate lakes, by D. A. Rickert and A. M. Spieker, 1972, 19 p.

601-H. Role of water in urban planning and management, by

W. J. Schneider, D. A. Rickert and A. M. Spieker, 1973, p.

601-I. Water facts and figures for planners and managers, by J. H. Feth, 1973,30 p.

601-J. Extent and development of urban flood plains, by W. J. Schneider and J. E. Goddard, 1974, 14 p.

631. Disposal of liquid wastes by injection underground--neither myth nor millennium, by A. M. Piper, 1969, 15 p.

643. Reconnaissance of selected minor elements in surface waters of the United States, October 1970, by W. H. Durum, J. D. Hem, and S. G. Heidel, 1971, 49 p.

645. A procedure for evaluating environmental impact, by L. B. Leopold, F. E. Clarke, B. B. Hanshaw, and J. R. Balsley, 1971, 13 p.

676. Estimated use of water in the United States in 1970, by

C. R. Murray and E. B. Reeves, 1972, 37 p.

703. Water demands for expanding energy development, by G. H. Davis and L. A. Wood, $1974,14 \mathrm{p}$.

719. The National Stream Quality Accounting Network (NASQAN)-some questions and answers, by J. F. Ficke and R. 0. Hawkinson, 1975, 23 p.

\section{Hydrologic investigations atlases}

61. Stream composition of the conterminous United States, by F. H. Rainwater, 1962 .

191. Availability of ground water in Tularosa basin and adjoining areas, New Mexico and Texas, by E. H. Herrick and L. V. Davis, 1965. 
193. Ground-water resources of the northern Tularosa basin near Carrizozo, Lincoln County, New Mexico, by J. B. Cooper, 1965.

194. Generalized map showing annual runoff and productive aquifers in the conterminous United States, compiled by C. L. McGuinnes, 1964 .

199. Preliminary map of the conterminous United States showing depth to and quality of shallowest ground water containing more than 1,000 parts per million dissolved solids, by J. H. Feth and others, 1965.

200. Chemical quality of public water supplies of the United States and Puerto Rico, 1962, by C. N. Durfor and Edith Becker, 1964.

212. Annual runoff in the conterminous United States, by M. W. Busby, 1966.

235. Temperature of surface waters in the conterminous United States, by J. F. Blakey, 1966.

318. Flood of August 1966 at Carlsbad, New Mexico, by L. P. Denis, 1968.

330. Ground water in the Ogallala Formation in the southern High Plains of Texas and New Mexico, by J. G. Cronin, 1969.

447. Selected hydrologic data in the upper Colorado River basin, by Don Price and K. M. Wadde11, 1973 (1974).

478. Quality of ground water in the lower Colorado River region, Arizona, Nevada, New Mexico, and Utah, by L. R. Kister, 1973.

510. Reconnaissance investigation of ground water in the Rio Grande drainage basin--with special emphasis on saline ground-water resources, by T. E. Kelly, 1974 .

Open-file reports of the U.S. Geological Survey.--Open-file reports are available for reference in the Albuquerque, New Mexico, and Reston, Virginia, offices of the U.S. Geological Survey; copies ordinarily are not reproduced for distribution. Further information may be obtained from the District Chief, Water Resources Division, Albuquerque.

\section{(a) Unnumbered open-file reports:}

Basler, J. A., and Alary, L. J., 1968, Quality of the shallow ground water in the Rincon-Mesilla Valleys [Dona Ana County], New Mexico and Texas, $30 \mathrm{p}$. 
Borland, J. P., 1970, A proposed streamflow-data program for New Mexico, $71 \mathrm{p}$.

Cooper, J. B., 1968, Ground-water exploration in the Bosque del Apache Grant, Socorro County, New Mexico, 79 p.

1973, Summary records of test and supply wells in range areas, White Sands Missile Range [Dona Ana and Otero Counties], New Mexico, $132 \mathrm{p}$.

Cox, E. R., and Havens, J. S., 1971, An appraisal of potential water salvage in the Lake McMillan delta area, Eddy County, New Mexico, 72 p.

1969, Availability of ground water near Arena, Luna County, New Mexico.

Hiss, W. L., Trantolo, A. P., and Sparks, J. L., 1969, New Mexico costanalysis system, $113 \mathrm{p}$.

Kelly, T. E., 1972, Water sources for nesting habitat of Mexican Duck and Double-Crested Cormorant at Elephant Butte Marsh, Sierra County, New Mexico, 29 p.

Kelly, T. E., 1973, Summary of ground-water data, Post Headquarters and adjacent areas, White Sands Missile Range [Dona Ana County], 66 p.

Koopman, F. C., 1971, Open-channel integrating-type flow meter, 25 p.

Koopman, F. C., Basler, J. A., and Lappala, E. G., 1970, Investigation of a water supply near Encino [Torrance County], New Mexico, in relation to high-energy detonations, $42 \mathrm{p}$.

Lyford, F. P., 1970, Test we11s T-15, T-16, T-17, T-18, and RC-3, White Sands Missile Range, Dona Ana and Sierra Counties, New Mexico, 46 p.

1972, The nature and extent of peat deposits and possible effects of peat mining on manmade features and springs near Mescalero [Otero County], New Mexico, 24 p.

Mercer, J. W., and Cooper, J. B., 1970, Availability of ground water in the Gallup-Tohatchi area, McKinley County, New Mexico, 182 p.

Mourant, W. A., 1971, Saturated thickness of Post-Mesozoic deposits in the northern (Map LN-4) and central (Map LC-4) part of Lea County, New Mexico, 2 maps.

1972, A proposal for a study of the water resources of Santa Fe County, New Mexico, 54 p. 
Scott, A. G., 1970, Estimated mean-annual runoff at Post Headquarters area, White Sands Missile Range [Dona Ana County], 13 p.

1971, Preliminary flood-frequency relations and summary of maximum discharges in New Mexico, 76 p.

Shomaker, J. W., 1971, Water resources of Fort Wingate Army Depot and adjacent areas, McKinley County, New Mexico, 228 p.

1971, Gains and losses in Pecos River between Alamogordo Dam and Acme [De Baca and Chavez Counties], New Mexico, 39 p.

Welder, G. E., 1971, Map showing chloride content of water from selected wells finished in the shallow aquifer, Roswell basin, [Chavez and Eddy Counties], New Mexico, August-October 1970.

1973, Base flow in the Acme-Artesia reach of the Pecos River [Chavez and Eddy Counties], New Mexico, 1957-71, 50 p.

\section{(b) Numbered open-file reports:}

75-406. Evaluation of monitoring of radioactive solid-waste burial sites at Los Alamos [Los Alamos County], New Mexico, by T. E. Kelly, $1975,82 \mathrm{p}$.

76-171. Factors altering the microclimate in Carlsbad Caverns [Eddy County], New Mexico, by J. S. McLean, 1976, 59 p.

76-414. Flood discharges of streams in New Mexico as related to channel geometry, by A. G. Scott, and J. L. Kunkler, 1976, 38 p.

77-123. Review and analysis of hydrogeologic conditions near the site of a potential nuclear-waste repository, Eddy and Lea Counties, New Mexico, by J. W. Mercer and B. R. Orr, 1977, 35 p.

77-314. Hydrologic maps and data in the Mimbres basin [Grant County], New Mexico, by J. S. McLean, 1977, 531 p.

77-330. Annual water-resources review, White Sands Missile Range, 1976, by R. R. Cruz, 1977, 27 p.

77-505. Map showing the altitude and configuration of the water level in the shallow aquifer, January 1975, Roswell Basin, Chaves and Eddy Counties, New Mexico, by G. E. Welder, 1977.

77-586. Sediment trap efficiency of Tortugas Arroyo near Las Cruces

[Dona Ana County], New Mexico, water years 1963-1974, by

D. E. Funderburg and F. E. Roybal, 1977, 56 p. 
Water-resources investigations (WRI) reports of the U.S. Geological Survey.--Reports in this series are available for inspection only at the Albuquerque, New Mexico, and Reston, Virginia, offices of the U.S. Geological Survey. Selected reports may be purchased either as microfilm or hard copy from the National Technical Information Service (NTIS), U.S. Department of Commerce, Springfield, Virginia 22161. Where appropriate, the NTIS ordering number is given in parentheses at the end of the citation. Further information about these reports may be obtained from the District Chief, Water Resources Division, Albuquerque.

43-73. Flood of July 17, 1972 in Gallup, New Mexico, by L. A. Waite, $1973,8 \mathrm{p}$.

77-98. Evaluation of a potential well field near Church Rock as a water supp1y for Gallup, New Mexico, by G. A. Hearne, 1977, 21 p.

Other publications.--(Address inquiries about availability of these reports to the publishers)

Ballance, W. C., 1967, Arkansas River basin--geography, geology, and hydrology, in Water resources of New Mexico, New Mexico State Engineer, compiler: Santa Fe, New Mexico, State Planning Office, p. 13-38.

Ballance, W. C., and Titus, F. B., Jr., 1967, Southern High Plains-geography, geology, and hydrology, in New Mexico State Engineer, compiler, Water resources of New Mexico: Santa Fe, New Mexico, State Planning office, p. 41-59.

Berkstresser, C. F., Jr., and Mourant, W. A., 1966, Ground-water resources and geology of Quay County, New Mexico: New Mexico Bureau Mines and Mineral Resources Ground-water Report 9, 115 p.

Cooper, J. B., and Davis, L. V., 1967, General occurrence and quality of ground water in Union County, New Mexico: New Mexico Bureau Mines and Minera1 Resources Ground-water Report 8, 113 p.

Cooper, J. B., and John, E. C., 1968, Geology and ground-water resources of southeastern McKinley County, New Mexico: New Mexico State Engineer Technical Report 35, $108 \mathrm{p}$.

Cooper, J. B., and Trauger, F. C., 1967, San Juan River basin--geography, geology, and hydrology, in New Mexico State Engineer, compiler, Water resources of New Mexico: Santa Fe, New Mexico, State Planning Office, p. 185-197.

Dinwiddie, G. A., 1967, Rio Grande basin--geography, geology and hydrology, in New Mexico State Engineer, compiler, Water resources of New Mexico: Santa Fe, New Mexico, State Planning Office, p. 129-168. 
Dinwiddie, G. A., and Clebsch, Alfred, Jr., 1973, Water resources of Guadalupe County, New Mexico: New Mexico State Bureau Mines and Mineral Resources Hydrologic Report 3, 43 p.

Dinwiddie, G. A., Mourant, W. A., and Basler, J. A., 1966, Municipal water supplies and uses, northwestern New Mexico: New Mexico State Engineer Technica1 Report 29C, 197 p.

1966, Municipal water supplies and uses, southwestern New Mexico: New Mexico State Engineer Technical Report 29D, 98 p.

Doty, G. C., 1967, Southwestern closed basins--geography, geology, and hydrology, in New Mexico State Engineer, compiler, Water resources of New Mexico: Santa Fe, New Mexico, State Planning Office, p. 251-276.

Hale, W. E., Reiland, L. J., and Beverage, J. P., 1965, Characteristics of the water supply in New Mexico: New Mexico State Engineer Technical Report $31,131 \mathrm{p}$.

Hiss, W. L., 1971, Water-level changes in the Permian Capitan aquifer, Eddy and southern Lea Counties, New Mexico: New Mexico Professional Engineer, v. 23, no. 11, p. 16-22.

1974, Chloride-ion concentration in ground water in Guadalupian rocks, southeast New Mexico and west Texas: New Mexico Bureau of Mines and Mineral Resources Resource Map 4.

Hudson, J. D., 1975, Ground-water levels in New Mexico, 1975: New Mexico State Engineer Basic-Data Report, 128 p.

Koopman, F. C., Trauger, F. D., and Basler, J. A., 1969, Water resources appraisal of the Silver City area, New Mexico: New Mexico State Engineer Technical Report 36, 96 p.

Kunkler, J. L., 1972, Saline ground water in east-central New Mexico, in Guidebook to east-central New Mexico: New Mexico Geological Society, 23rd Field Conference, p. 208-209.

McLean, J. S., 1970, Saline ground-water resources of the Tularosa basin, New Mexico: U.S. Dept. of the Interior, Office of Saline Water, Research and Development Progress Report No. 561, 126 p.

Mercer, J. W., 1969, Hydrology of Project Gasbuggy site, Rio Arriba County, New Mexico: U.S. Atomic Energy Commission Technical Information Service PNE-G-60, 45 p. Available from U.S. Dept. of Commerce, NTIS, Springfield, VA.

Mercer, J. W., and Lappala, E. G., 1972, Ground-water resources of the Mora River drainage basin, western Mora County, New Mexico: New Mexico State Engineer Technical Report 37, 138 p. 
Mourant, W. A., 1967, Pecos River basin--geography, geology, and hydrology, in New Mexico State Engineer, compiler, Water resources of New Mexico: Santa Fe, New Mexico, State Planning Office, p. 61-96.

Mourant, W. A., and Shomaker, J. W., 1970, Reconnaissance of water resources of De Baca County, New Mexico: New Mexico State Bureau of Mines and Mineral Resources Ground-water Report 10, 87 p.

Reeder, H. 0., Bjorklund, L. J., and Dinwiddie, G. A., 1967, Quantitative analysis of water resources in the Albuquerque area, New Mexico: New Mexico State Engineer Technical Report 33, 34 p.

Titus, F. B., 1967, Central closed basin--geography, geology, and hydrology, in New Mexico State Engineer, compiler, Water resources of New Mexico: Santa Fe, New Mexico, State Planning Office, p. 99-126.

Trainer, F. W., 1975, Mixing of thermal and nonthermal waters in the margin of the Rio Grande rift, Jemez Mountains, New Mexico, in Guidebook to Las Cruces Country: New Mexico Geological Society, $\overline{26}$ th Field Conference, p. 213-218.

Trauger, F. D., 1967, Lower Colorado River basin--geography, geology, and hydrology, in New Mexico State Engineer, compiler, Water resources of New Mexico:- Santa Fe, New Mexico, State Planning office, p. 213-229.

1972, Water resources and general geology of Grant County, New Mexico: New Mexico State Bureau of Mines and Mineral Resources Hydrologic Report 2, 556 p.

U.S. Geological Survey, 1975a, Water-resources data for New Mexico-Surface-water records, New Mexico State Engineer Annual Report, 603 p.

1975b, Water-resources data for New Mexico--Water-quality records, New Mexico State Engineer Annual Report, 238 p.

Reports of the New Mexico District, Fiscal Year 1977

Cruz, R. R., 1977, Annual water-resources review, White Sands Missile Range, 1976, Open-File Report 77-330, 27 p.

Funderburg, D. E., 1977, Trap-efficiency investigation, Bernalillo Floodwater Retarding Reservoir No. 1 (Piedra Lisa Arroyo) near Berna1i11o, New Mexico, water years 1956-1974, Open-File Report 77-261, 52 p.

Funderburg, D. E. and Royba1, F. E., 1977, Sediment trap efficiency of Tortugas Arroyo near Las Cruces, New Mexico, water years 1963-1974, Open-File Report 77-586, 56 p. 
Hearne, G. A., 1977, Evaluation of a potential well field near Church Rock as a water supply for Gallup, New Mexico, Water Resources Investigations Report 77-98, 21 p.

McLean, J. S., 1977, Hydrologic maps and data in the Mimbres Basin, New Mexico, scale $1: 48,000$ ( 1 inch $=4,000$ feet), Open-File Report 77-314, $531 \mathrm{p}$.

Mercer, J. W. and Orr, B. R., 1977, Review and analysis of hydrogeologic conditions near the site of a potential nuclear-waste repository, Eddy and Lea Counties, New Mexico, Open-File Report 77-123, $35 \mathrm{p}$.

U.S. Geological Survey, 1976, Water Resources data for New Mexico-Water Year 1975,617 p.

1976, Water Resources data for New Mexico--Calendar Year 1975, 597 p.

1977, Water Resources data for New Mexico--Water Year 1976, 666 p.

Welder, G. E., 1977, Map showing the altitude and configuration of the water level in the shallow aquifer, January 1964, Roswel1 basin, Chaves and Eddy Counties, New Mexico, scale 1:125,000 (1 inch = about 2 miles), Open-File Map 77-506, 2 sheets.

1977, Map showing the altitude and configuration of the water level in the shallow aquifer, January 1975, Roswell basin, Chaves and Eddy Counties, New Mexico, scale 1:125,000 (1 inch = about 2 miles) Open-File Map 77-505, 2 sheets. 


\section{NAWDEX}

The concept and purpose of NAWDEX

NAWDEX (National Water Data Exchange) is a confederation of water-oriented organizations working together to provide timely and convenient access to their data. This concept is directed at closer coordination of water-data dissemination activities; improving communication within the water-data community; more effectively utilizing the data resources, expertise, and talent within the community; improving the quality and efficiencies of techniques and procedures used for the exchange of water data; and providing water data to those who need these data in a cost-effective manner.

The purpose of NAWDEX is to identify sources of water data and to provide the linkage between those who acquire and those who use water data. The mission is being accomplished by establishing better communication between water-oriented organizations, acquiring as much information as possible on available water data, and making this information readily available to water-data users.

\section{The organization of NAWDEX}

NAWDEX is centrally managed by a Program office located within the U.S. Geological Survey's Water Resources Division in Reston, Virginia. This office provides the coordination for all NAWDEX activities; develops the technical systems and procedures necessary for the operation of NAWDEX; maintains the data bases and other information resources required for operation; provides operational guidelines to all service centers; and serves as a liaison between members, external organizations, advisory committees, and the users of NAWDEX services and facilities.

The basic components of NAWDEX are organizations that become participating members. They are organizations that are collectors of water data, contributors from the water-data community who provide support toward program improvement, collectors of data related to water-resources activities, and users of water data. All members contribute support toward improvements in data exchange procedures and techniques. 
Membership in NAWDEX is voluntary and open to any organization active in the field of water resources. This includes organizations from the federal, state, interstate, local governmental, academic, and private sectors of the water-data community. There are no dues or fees associated with membership. Members are required, however, to sign a Memorandum of Understanding with the Program Office which defines that office's responsibilities and a general commitment of the member to take an active role in NAWDEX activities, to provide information on its data holdings for indexing purposes, and to provide data from its holdings upon request. The Program office is not empowered to sign membership documents with foreign or international organizations. These organizations are invited, however, to participate in NAWDEX through an established relationship with the Program office and will be identified in NAWDEX as foreign affiliates.

Each member takes an active role in the planning, development, and execution of NAWDEX activities. Each member is an advisor to the Program office and mechanisms exist to assure continued communication between members, to assure active participation of all members in an equal and equitable manner, and to maintain an awareness of the needs of the water-data community in order to achieve maximum program effectiveness.

\section{NAWDEX services}

A variety of services are provided by NAWDEX to assist its users to identify needed water data, to locate these data, and to refer users to the proper sources for obtaining the data. It is not a function of NAWDEX to become a repository of water data. Instead, the data held by NAWDEX members are indexed by the Program office to provide a central source of information on water data available from a large number of organizations.

NAWDEX services are provided through the Program office and a nationwide network of Local Assistance Centers. This network was established in January 1977 and consists of 51 centers located in 45 states and Puerto Rico. The centers provide convenient access to NAWDEX services as well as making local-area expertise available in the identification and location of needed data. 
The New Mexico District Office of the Water Resources Division, U.S. Geological Survey has been designated the Local Assistance Center for New Mexico. All requests to the Local Assistance Center should be addressed to:

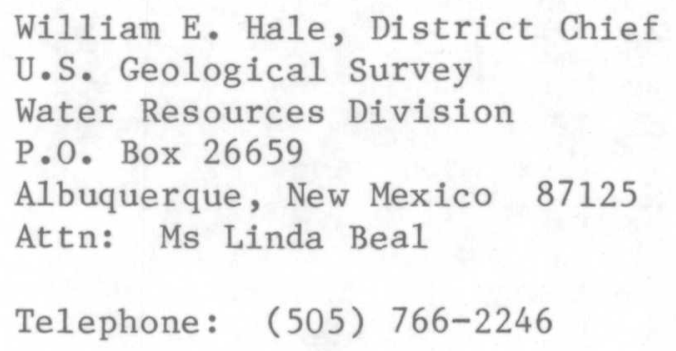

For other services or additional information, contact: NAWDEX, U.S. Geological Survey, 421 National Center, Reston, Virginia 22092, Telephone (703) 860-6031. 